\title{
Identification of the factors of socio-cultural environment affecting the physical activity students: a qualitative study
}

AkramSadeghpour

Ph.D. In Sport Management, Department of Sport Management, Faculty of Physical Education and Sport Sciences, Isfahan (Khorasgan) Branch, Islamic Azad University, Isfahan, Iran.

Mohammad Ehsani

Professor in Sport Management, Department of Sport Sciences, Faculty of Humanities, Tarbiat Modares University, Tehran, Iran. (Correoponding Author) Ehsani@modares.ac.ir

\section{Marjan Saffari}

Assistant Professor, Department of Sport Management, Faculty of Humanities, Tarbiat Modares University, Tehran, Iran.

Fereshteh Zamani-Alavijeh

Department of Health Education and Promotion, School of Health, Isfahan University of Medical Sciences, Isfahan, Iran.

Received: 17 July 2019

Accepted: 11 November 2019

Doi: 10.29252/ijhehp.8.1.5.57

\section{ABSTRACT}

Background and Objectives: Studies of variables related to the levels of student physical activity can provide an active lifestyle throughout their lives. Thus, this study was conducted to identify the factors affecting the socio-cultural environment in physical activity of students of Iranian University of Medical Sciences.

Materials and Methods: This study was a qualitative content analysis with a deductive-inductive approach. Participants were 23 individuals (20 males and 3 females) of physical activity experts and 16 students ( 7 females and 9 males) who reached theoretical saturation with 21 interviews with professors and 2 focal sessions with students. Samples (experts) were selected based on the snowball sampling method and the students were randomly assigned to the focal sessions. The interviews were conducted in a semi-structured manner and the data were analyzed at the same time as the data were collected and manually analyzed. Results: In the study of social factors related to physical activity, 3 main categories, the role of family and friends, with subcategories (accompaniment, role modeling, facilitator, instrumental and direct support), coaches and expert support (communication support, support Competence and independence, reinforcing social morality, and normative and cultural barriers (cultural gender rules and stereotypes and gender differences) were extracted.

Conclusion: The identified variables of research are important in the realization of student physical activity behavior and help relevant organizations such as the Ministry of Health and Medical Education, universities and other related areas to plan health promotion and create a healthy lifestyle for students.

Keywords: Socio-cultural environment, Students, Physical activity, Qualitative Study Paper Type: Research Article.

Citation (Vancouver): Sadeghpour A, Ehsani M, Saffari M, Zamani-Alavijeh F. Identification of the factors of socio-cultural environment affecting the physical activity students: a qualitative study. Iran J Health Educ Health Promot. Spring 2020;8(1): 57-71. [Persian]

Citation (APA): Sadeghpour A., Ehsani M., Saffari M., Zamani-Alavijeh F. (Spring 2020). Identification of the factors of socio-cultural environment affecting the physical activity students: a qualitative study. Iranian Journal of Health Education \& Health Promotion., 8(1), 57-71. [Persian] 


\section{شناسايى عوامل محيط اجتماعى- فرهنغى موثر بر فعاليت بدنى دانشجويان: \\ يك مطالعه كيفى}

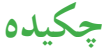

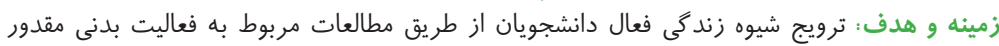

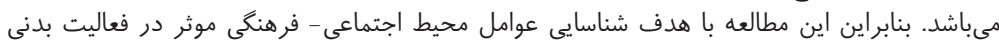

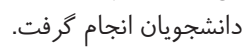

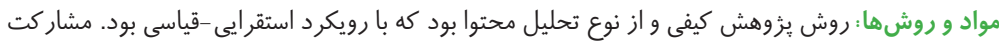

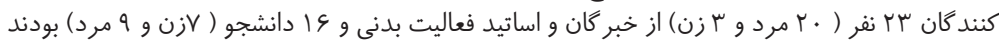

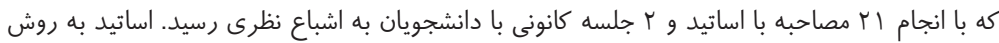

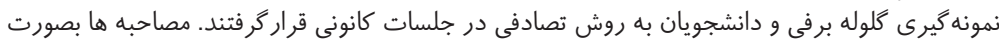

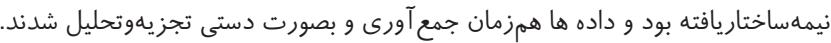

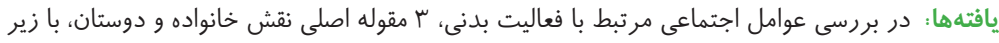

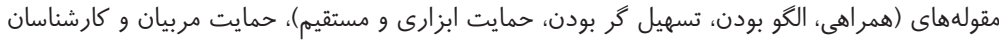

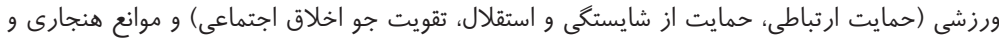

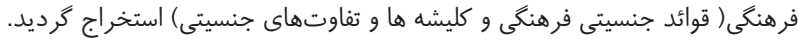

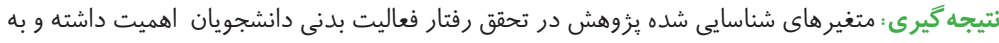

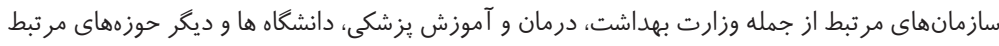

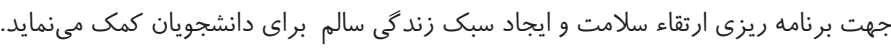

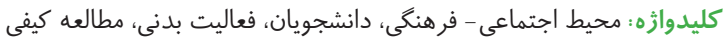

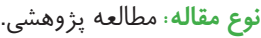

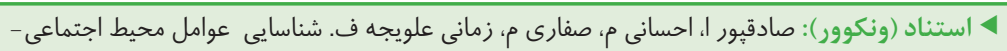

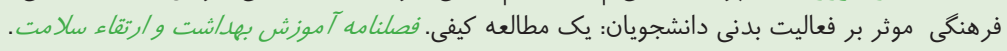
بهار

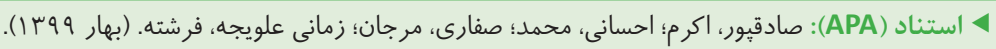

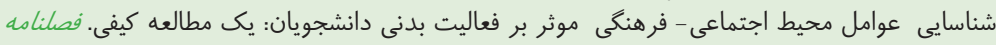

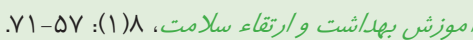

اكرم صادقيور

دكترى مديريت ورزشى، دانشكده تربيت بدنى و و وادور علوم ورزشى، دانشكاه آزاد اسلامى وانكد واحد اصفهان (خوراسگان)، اصفهان، ايران

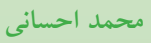

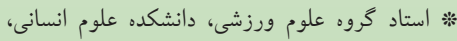
دانشكاء تربيت مدرس، تهران، ايران (نويسنده مسئول). Ehsani@modares.ac.ir

مر جان صفارى استاديار كروه علوم ورزشى، دانشكده علوم انسانى، تران

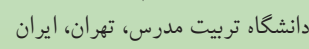
فرشته زمانى علو ديجه

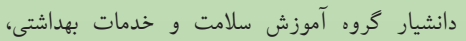

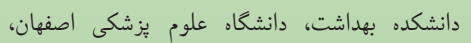
اصفهان، ايران

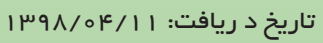

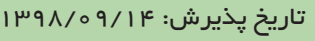



خصوص شناسايى اين عوامل اهميت بسيارى بيدا مى كند كه شايد انجام مطالعات بصورت كيفى در اين زمينه، مفيد به نظر برسد، بنابراين در مطالعه حاضر از مطالعه كيفى استفاده شد، تا به محقّق

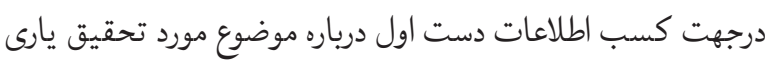
دهد. روشهاى كيفى زمينه را براى درك و مداخله بيشتر و بهتر در عرصه ى يُوهش، به ويزّه در قلمرو مطالعات انسانى، فراهم مى

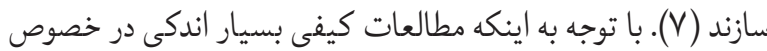

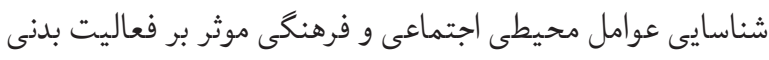
دانشجويان انجام كرفته و شناسايي عميق علل عدم تمايلات جامعهد دانشخاهى ايران به ويثه دانشجويان، به فعاليتهاى بدنى و ورزش و و شناخت عوامل محيطى موثر بر فعاليت بدنى دانشجويان ضرورت

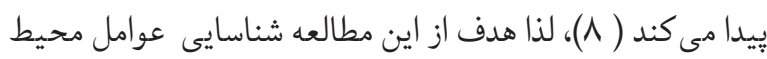
اجتماعى-فرهنكى موثر بر فعاليت بدنى دانشجويان در دانشگاههاى علوم يزشكى ايران، از طريق يك مطالعه كيفى مىباشد.

$$
\text { روش برورسى }
$$

اين مطالعه، به روش تحليل محتوى كيفى و با رويكرد استقرايى-

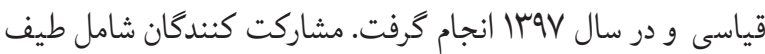
متنوعى از خبركان ورزش ايران بودند كه بر اساس نمونه گيرى گلولوله

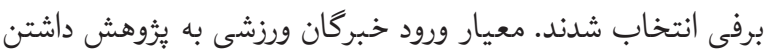
آكاهى و دانش كافى در زمينه موضوع مطالعه، و حداقل ه سال تجربه

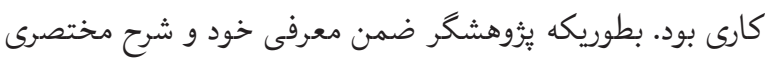

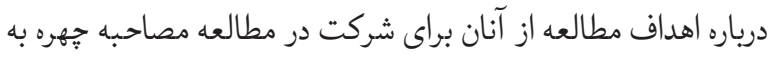

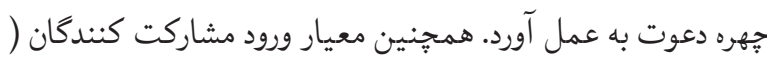

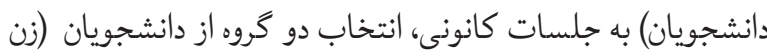
و مرد) بود كه گروه اول داراى تجربه فعاليت بدنى مستمر در دانشگاه علوم يُشكى اصفهان بودند كه با مراجعه به سالنهاى ورزشى دانشكاه بصورت تصادفى انتخاب شدند و گروه دوم، دانشجويان بدون فعاليت بدنى مستمر بودند كه بصورت تصادفى با مراجعه به دانشكده ها،

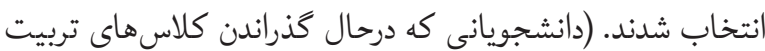

فعاليت بدنى به بهبود سلامت جسمانى و روانى كمك نموده و

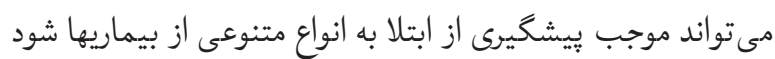

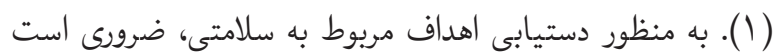

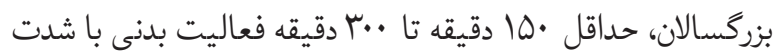
متوسط و يا VD دقيقه تا •lD دقيقه در هفته فعاليت بدنى شديد هوازى و يا تركيبى از فعاليت بدنى هوازى با شدت متوسط و يا

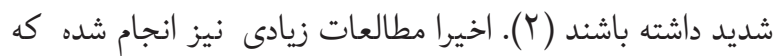
فقدان فعاليت بدنى را تقريبا در همه كشورها و در تمام سطوح سنى، مخصوصا در كروه سنى جوانان دانشعاهى نشان مىدهد (1) و شواهد موجود نيز نشان مىدهند كه يك سوم از دانش آموزانى

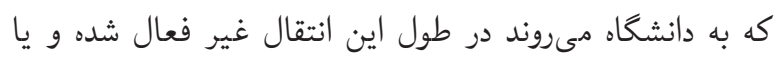
داراى فعاليت كمترى هستند (ץ). بنابراين بررسى دقيق عوامل و و

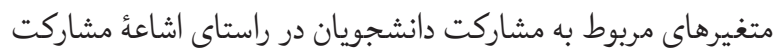
در فعاليتهاى ورزشى، جه از نظر ارتقاى سطح سلامتى و افزايش سلامت اجتماعى، و جه از منظر فرهنگ سازى و بسترسازى در

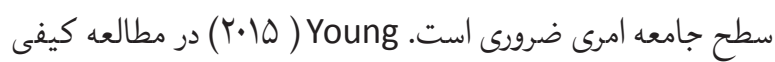
خود بيان داشت كه \%٪ دانشجويان به عنوان داراى اضافه وزن و يا حاق طبقه بندى شدند و اكثر مشاركت كنندكان فعاليتهاى بدنى منظمى نداشتند تا از مزاياى سلامتى آن بهره مند شوند و اكر فئر

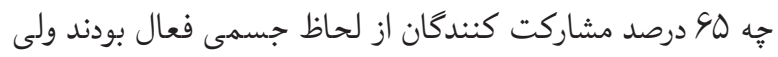
فقط يك پِنجم، حداقل دستور العملهاى فعاليت بدنى را برآورده

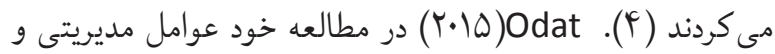

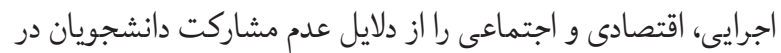

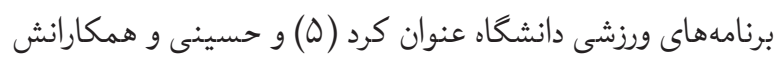
(Y. (Y. در مطالعه خود بيان داشتند كه مهمترين عوامل اثر كذار بر مشاركت دانشجويان در فعاليتهاى بدذى نخست عامل مديريتى

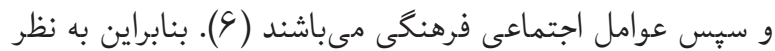
مىرسد عوامل اجتماعى و فرهنكى نقش مهمى در اين زمينه داشته

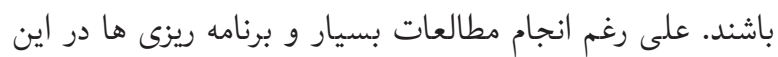
زمينه، گسترش عدم تمايل به فعاليت بدنى و ورزش در دانشجويان 
فرايند انجام مصاحبه و كدكذارى بيش از يك سال طول كشيد و

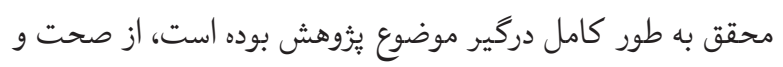

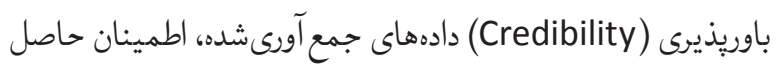

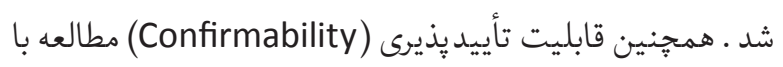

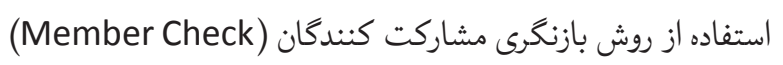

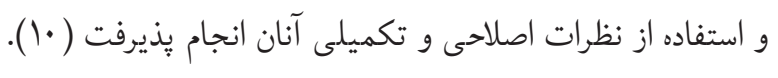

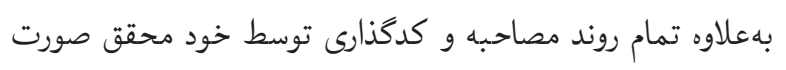
كرفت و تمام فرآيند تحقيق توسط دو استاد صحب نظرنظارت ونات شد. انتخاب مشاركت كنندگان با حداكثر تنوع (از نظر سن، تجريه كارى و...)، انتقال يذيرى (Transferability) دادهها را فراهم آورد و ثبات يافته ها نيز با نسخه نويسى و ارائه مثالهاى نقل قول هاى

مستقيم امكان يذير كرديد ( (II).

يافتنه ها مشخصات كلى مشار كت كنند مان خبرگان و اساتيد: بآ٪ از مصاحبه شوندگان (اساتيد و خبركان)

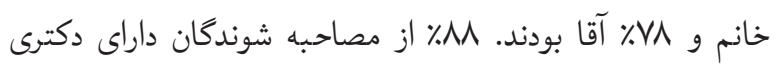

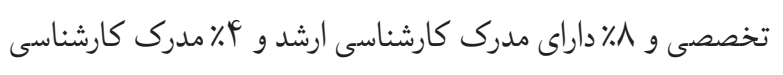
بودند. بN٪ از مصاحبه شوندگان در رشته تربيت بدنى و و علوم

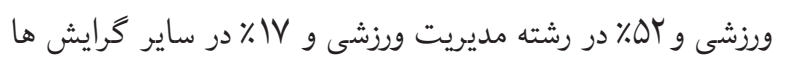
تحصيلات عاليه داشتند.

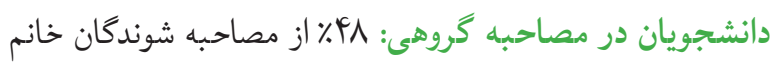

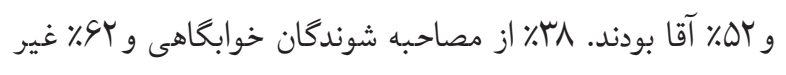

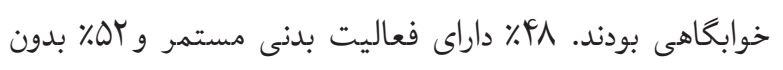

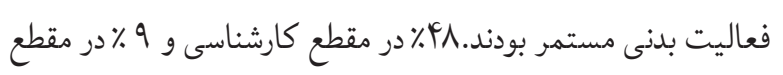

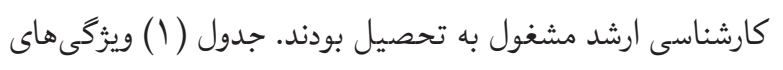
مصاحبه شوندكان را نشان مى دهد. بطور كلى در اين مطالعه در مجموع، 909 كد اوليه، بامقوله

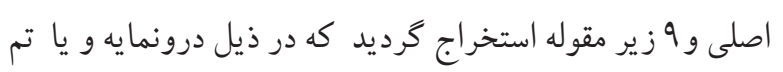
اصلى محيط اجتماعى جاى داده شدند.
بدنى درسى بودند و دانشجويانى كه تمايلى به مصاحبه نداشتند از

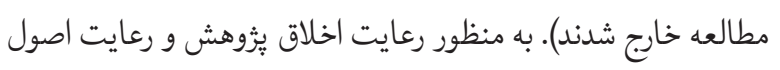

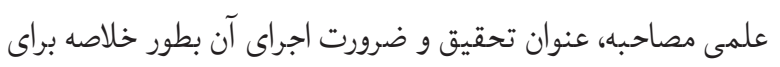

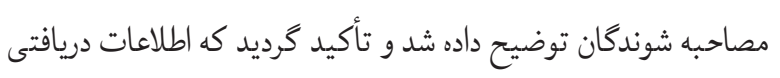

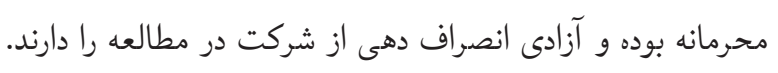

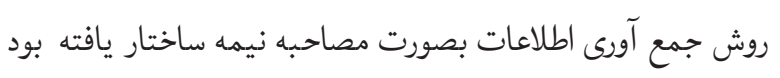
و راهنماى مصاحبه توسط ب نفر از اساتيد مجرب دانشعاه (در رشته مديريت ورزشى) مورد بازبينى و كنترل قرار گرفت. نمونه سوالات

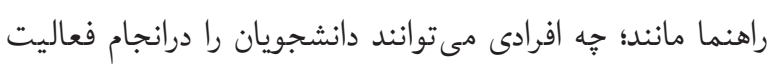
بدنى حمايت كنند؟ (مصاحبه با خبركان)، عوامل اجتماعى مؤثر

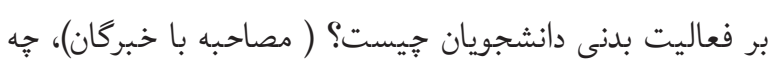

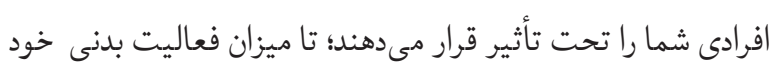

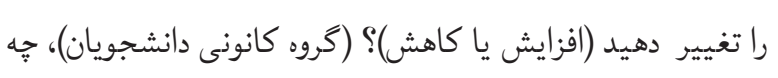

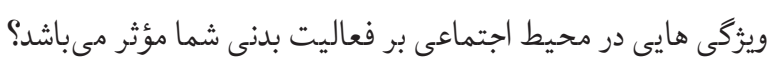

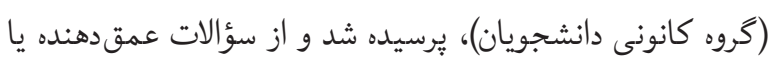
كاوشى نيز براى تبيين بيشتر جزئيات مورد نظر و افزايش عمق دونق

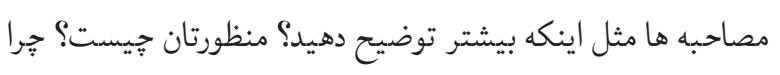

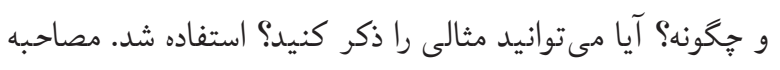

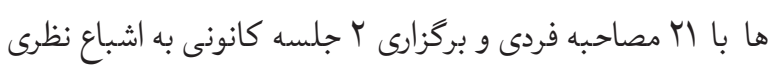

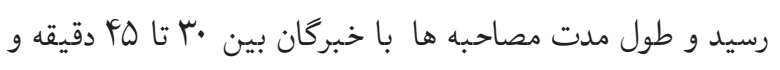

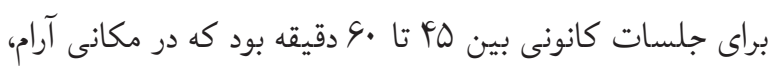

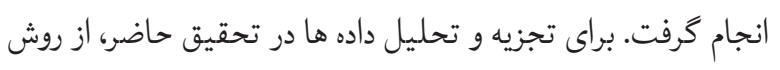

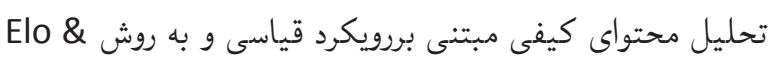
Kyngas متن، "واحدهاى معنا" شناسايى و كدگذارى شد تا كلماتى از متن

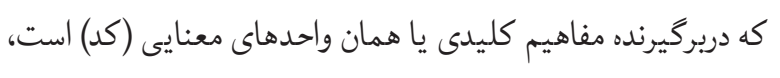

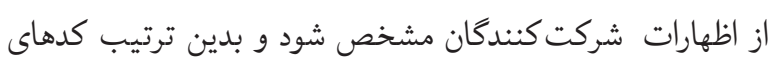

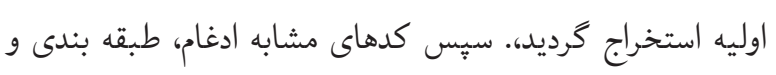

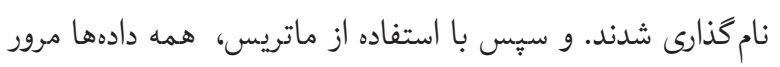
و در ذيل درونمايه و يا تم اصلى محيط اجتماعى كنجانده شدند.

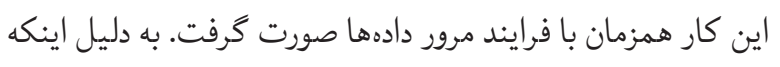




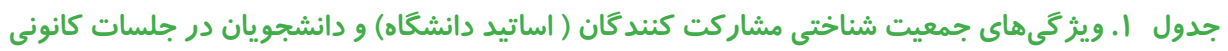

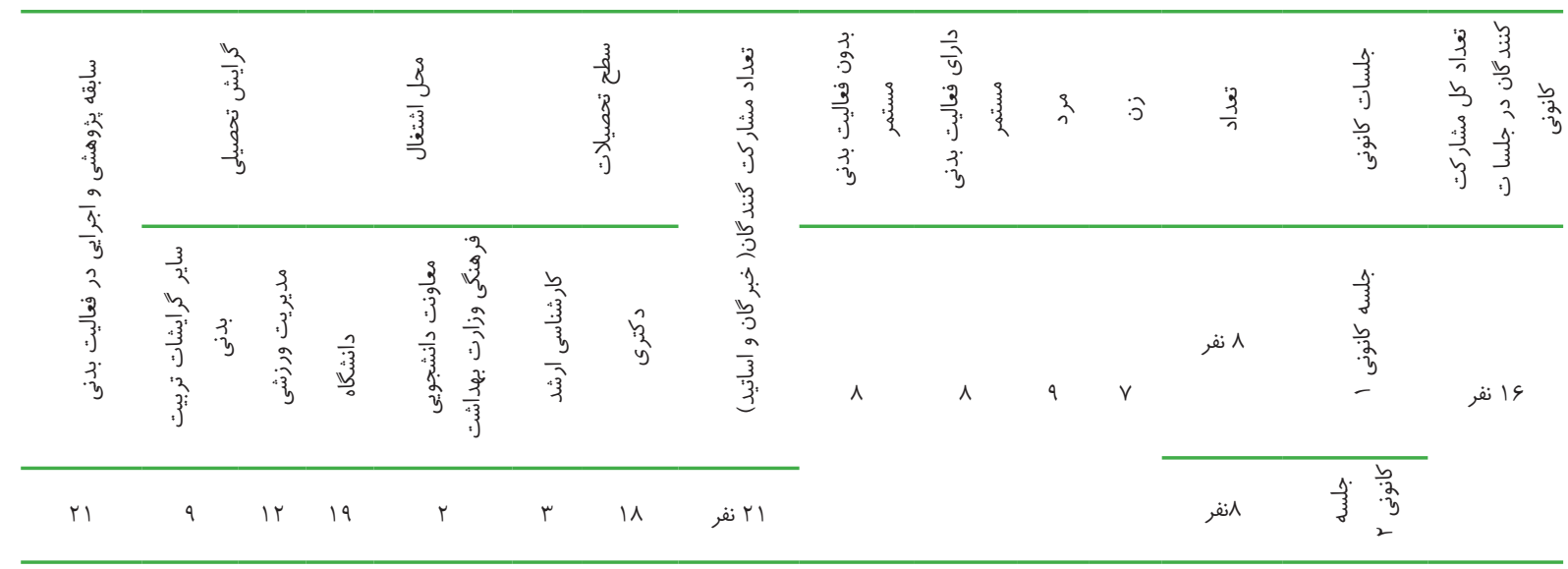

"من با خانوادهام جمعه ها كوه مىرفتيم، و اين خيلى برم لذت

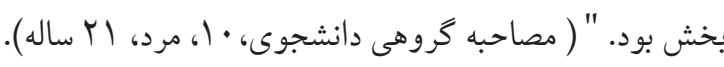
داشتن همر اه ورزشى و همجنين پيشنهاد انجام فعاليت بدنى توسط والدين و يا دوستان نيز در فعاليت بدنى دانشجويان موثر بود:

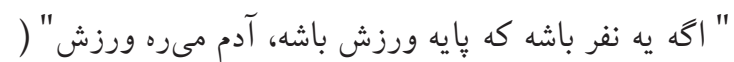
مصاحبه گروهى دانشجوى (، زن، · ب ساله). " يدرم بعضى اوقات به من مى گه كه آخر هفته ها بريم كوه صفه" ( مصاحبه گروهى دانشجوى، • (ل، مرد، آ ساله). بعلاوه فراهم بودن شرايط تماشاى رويدادهاى مختلف ورزشى همراه با خانواده و يا دوستان (مانند تماشاى مسابقات و يا رقابت ها از طريق رسانه ها و يا تماشاى مسابقات در اماكن ورزشى با يكديخر)، مى تواند به شكل گيرى رفتار فعاليت بدنى كمك نمايد. بنابراين ويثز گیىاى ذكر شده فوق را مىتوان در زير مقوله "همر اهى خانواده و دوستان" دسته بندى نمود.

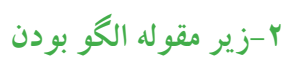
الخو بودن خانواده و دوستان فعال نيز مىتواند نقش مهمى براى انجام فعاليتهاى بدنى دانشجويان داشته باشند. بنا به اظهارات مشاركت كنندگان، شيوهایى مختلفى مانند مشاهده عادات رفتار فعاليت بدنى اعضاى خانواده و دوستان (مشاهده رفتار اعضاى خانواده، مشاهده رفتار فعاليت بدنى دوستان، سبك زندكى فعال و يا غير فعال والدين و...)، وجود وزشكار در خانواده و يا فاميل ( والدين ورزشكار، فاميل
درون مايه ( تم اصلى ) محيط اجتماعى نتايج تجزيه و تحليل يثوهش، در قالب امقوله اصلى و 9 زير مقوله با عنوان ا - نقش خانواده و دوستان؛ با زير مقولههاى همراهى، الخو بودن، تسهيل گر بودن، حمايت ابزارى و مستقيم والدين، بإ- مقوله اصلى حمايت مربيان و كارشناسان ورزشى؛ با زير مقولههاى حمايت ارتباطى، حمايت از شايستكى و استقلال، تقويت جو اخلاق اجتماعى و ب-مقوله اصلى موانع هنجارى و فرهنگى؛ با زير مقولههاى قوائد جنسيتى فرهنكى و كليشه ها و تفاوتهاى جنسيتى دسته بندى شدند. مقوله اصلى نقش خانو اده و دوستان در تجزيه و تحليل مصاحبه ها، مشاركت كنندگان، به اهميت خانواده و دوستان بر شكل گيرى رفتار فعاليت بدنى و ورزش تأكيد داشتند. 1 -زيرمقوله همراهى اعضاى خانو اده و دوستان بنا به اظهارات مشاركت كنندگان در اين بيزوهش، همراهى اعضاى خانواده و دوستان با دانشجويان از طريق شيوههاى مختلفى جون إن انجام فعاليت بدنى با خانواده و دوستان Y - ي يشنهاد انجام فعاليت بدنى از طرف خانواده و يا دوستان ب - تماشاى رويدادهاى ورزشى همراه با خانواده و يا دوستان در كرايش آنها به فعاليت بدنى اهميت داشته است. جملات زير مويد اين مطلبند: " مامانم هميشه با دوستش كه همسايمون هم بود، مىرفت براى بيادهروى تو يارى نزديك خونمون و منو هم اغلب با خودش مى برد" ( مصاحبه گروهى دانشجوى "ا، زن، آ ساله). 
دانشجو بشن" ( استاد Y). بنابراين ويز كىهاى ذكر شده فوق را مىتوان در زير مقوله "الكو بودن خانواده و دوستان "دسته بندى نمود. ب-زير مقوله تسهيل گر بودن

در تجزيه و تحليل مصاحبهها، مشاركت كنندكان، به نقش تشويق و

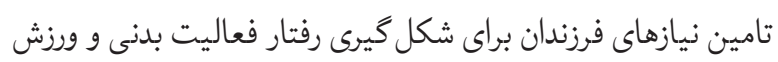

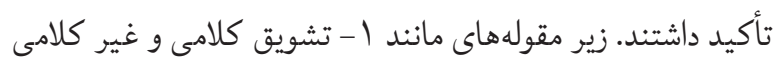

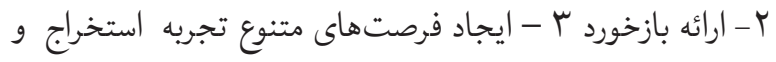
در زير مقوله "تسهيل گر بودن" قرار گرفتند. بنا به اظهارات مشار كت كنند كان، اعضاى خانو اده مى توانند

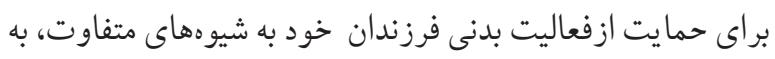

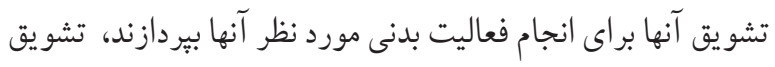

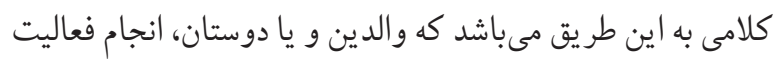

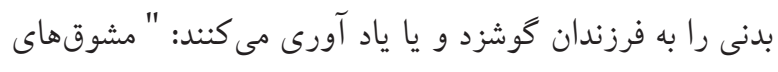
من براى ورزش يدر و مادرم هستند. الان هم كه اومدم دانشعاه

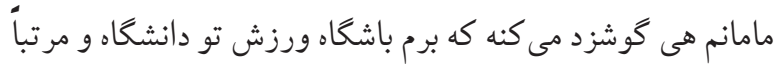

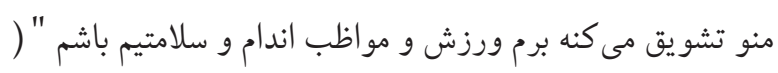

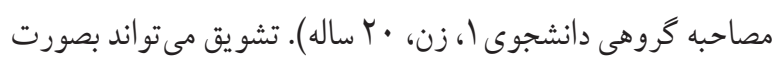

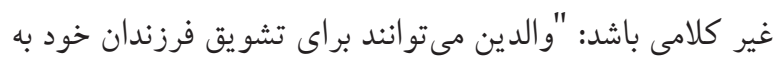

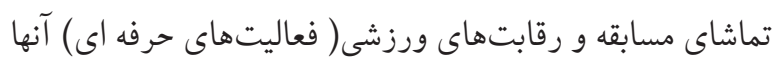

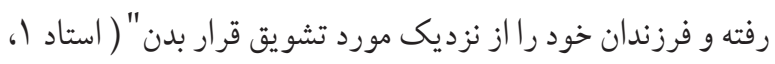

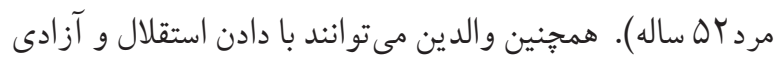

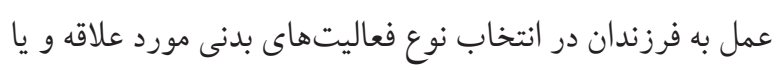

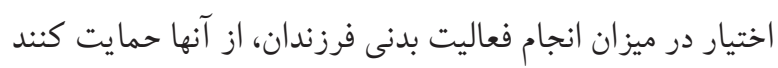
( استاد 19). به عقيده مشار كت كنند گان حمايت اجتماعى دوستان

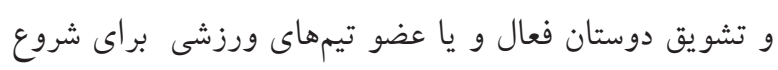

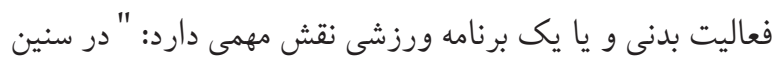

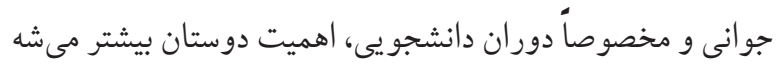

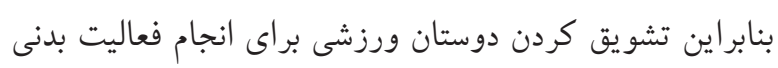

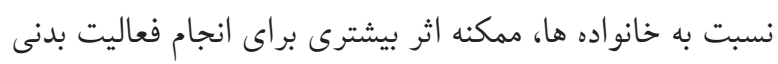

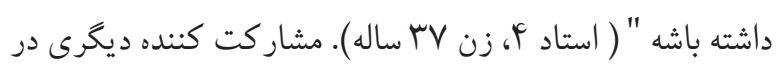

ورزشكار، داشتن قهرمان ورزشى در فاميل و يا خانواده)، الخوبردارى از فعاليتبدنى دوستان ( مشاهده دانشجويان قهرمان در رشته مورد علاقه، داشتن دوستان فعال، تقليد از فعاليت بدذى دوستان ) مي تواند در شكل گيرى و انجام فعاليت بدنى دانشجويان موثر باشد. بنا به

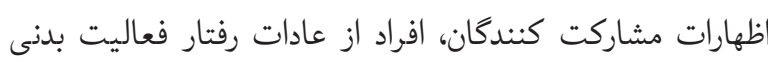

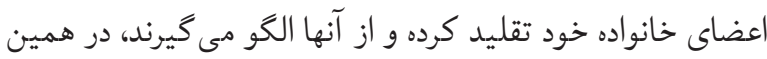

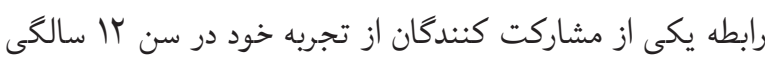
با مشاهده رفتار فعاليت بدنى برادرش، اينطور توضيح داد:

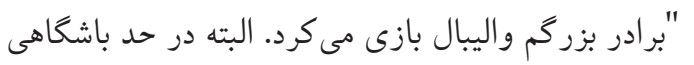

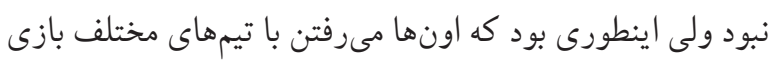

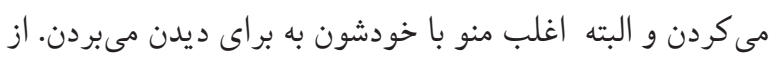

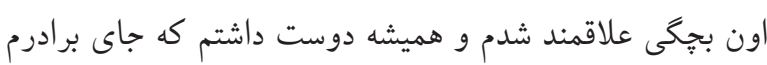

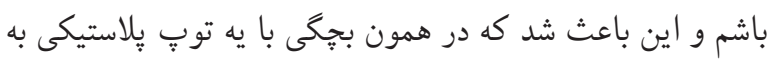

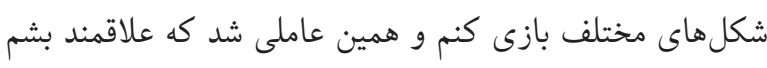
و بعدها برم تو تيم و اليبال مدرسهام" ( استاد ك، مرد هV ساله ماله). مشاركت كننده ديخرى در اين زمينه بيان داشت:

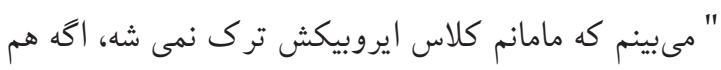

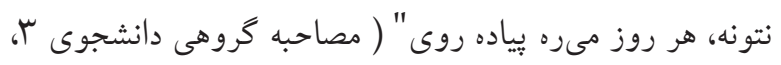
زن، آباله). از نظر مشاركت كنند كان، قهرمان بودن و يا حضور يك ورزشكار

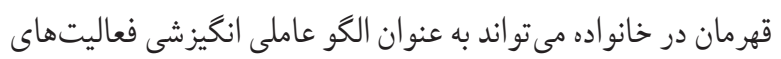

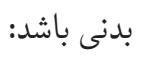
" يدرم يك شطرنج باز حرفهاى بود و قبلاً در استان هم مقام

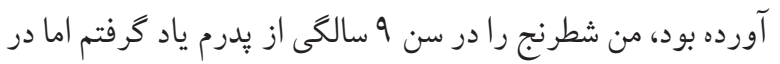
حد سر گرمى و تفريح باقى ماند اما در دوران دبيرستان و دانشكاه

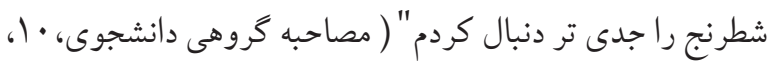

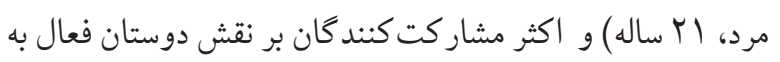

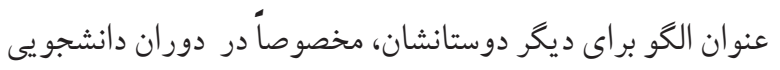

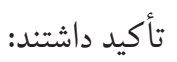
" دانشجو يان خيلى الكو يذيرن و دوستانى كه فعاليتبدنى دارن، خيلى مى تونن تأثير گذار باشن و حتى ممكنه باعث تغيير رفتار در 
و همينطور كارشناسان و كاركنان ادارات تربيت بدنى دانشخاه ها در حمايت و تشويق دانشجويان به سمت فعاليت بدنى و ورزش بسيار مهم و سازنده باشد. نتايج در اين مقوله در قالب سه زير مقوله (حمايت ارتباطى، حمايت از شايستگى و استقلال، تقويت جو اخلاق اجتماعى) دستهبندى گرديد. 1-زير مقوله حمايت ارتباطى بـى

در تجزيه و تحليل مصاحبهها، روابط اجتماعى مطلوب بين دانشجو و مربى و شيوههاى رفتارى مربيان مانند رفتار محترمانه با دانشجو، مراوده و تعامل با دانشجويان، عدم تخريب شخصيت دانشجو، برخورد صميمانه و گرم، ايجاد رابطه عاطفى، برقرارى رابطه ى خوب، دوستى با دانشجو يان، در دسترس بودن و امكان گفتخو و صحبت، توجه به دانشجويان و شناخت آنها مخصوصا در بدو ورود و از اين قبيل از مواردى بود كه توسط مشار كت كنند كان عنوان كرديد. استفاده از روشهاى ارتباطى سازنده همر اه با احترام متقابل علاوه بر تقويت روابط مربى - ورزشكار، ضامن ييامدها مثبت و دستاوردهاى مهمى در ورزش جه به شكل قهرمانى و جه به شكل تفر يحى است (Y Y). در واقع، شالوده مربيخرى ارتباط بوده و لزوم ايجاد ارتباطى نزديك، صميمانه و مستمر، همراه با رفتار توأم با احترام بين كارشناسان و مربيان ورزشى و دانشجو يان (مخصوصاً در بدو ورود دانشجويان )، مكرراً توسط همه مشاركت كنند گان بيان كرديد: "اولين تلاش مربيان بايد برقرارى يك رابطه مطلوب، دوستانه و حمايت كننده با دانشجويانشان باشد، مربيان بايد نشان بدهند كه دانشجو براشون مهمه و دانشجويان رفتارهايى كه توأم با بأ احترام از طرف مربى هستش رو درك مى كنند و اين متقابله "( استاد • أ، مرد او ساله). در خصوص ضرورت رفتار و برخورد صحيح كارشناسان و مربيان ورزش دانشعاه يك مشار كت كننده كفت: " ما با رفتارهاى مناسب و شيوههاى برخورد صحيح مىتوانيم در

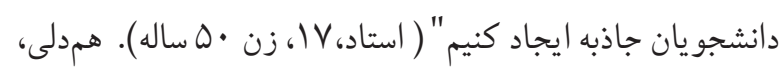
توانايى درى افكار، احساسات، هيجانات ورزشكار و حساس بودن مربيان در قبال دانشجو يان است و ايجاد همدلى و ارتباط عاطفى بين مربى و دانشجو نيز از موارد ذكر شده توسط برخى مشاركت
اين زمينه كفت: "...دوست خيلى موثره و من خودم تنها نمى روم و اكه دوستم تشو يقم كنه باهاش برم ممكنه برم "( مصاحبه گروهى دانشجوى ه، زن سب ساله). علاوه بر اين، بنا به اظهارات مشاركت كنندگان ؛ بازخورد و قضاوتهاى والدين و همجٍنين دوستان و همسالان ممكن است در شكل گيرى و يا ادامه رفتار فعاليت بدنى دانشجو يان موثر باشد و والدين مىتوانند با ايجاد فرصتهاى متنوع تجربه فعاليت بدنى و در معرض قرار دادن فرزندان با انواع فعاليت ها،آنها را براى فعاليت بدنى تشويق نمايند: "خوب من از وقتى با مامانم باشگاه ورزشى مىرفتم و تو ورزش هايى كه اون جا ديدم، به بسكتبال و شنا علاقمند شدم و هنوز هم تو اوقات فراغتم اين ورزش ها رو تفريحى انجام مىدهم "( مصاحبه گروهى دانشجوى | (ا، زن، MF ساله). بنابراين ويز گیىهاى ذكر شده فوق را مىتوان در زير مقوله " تسهيل گر " دسته بندى نمود. F - F ير مقوله حمايت ابزارى و مستقيم والدين تأمين نيازهاى ورزشى فرزندان از قبيل؛ تأمين هزينههاى ورزشى مانند فراهم كردن وسايل و تجهيزات ورزشى، يرداخت هزينهاى مربوط به ثبت نام كلاس ها و تسهيل رفت و آمد فرزندان از طريق بردن و يا آوردن فرزندان به محل ورزش نيز در تقويت و تشويق اين رفتار مؤثر است:" حمايتهاى مالى والدين براى شركت فرزندان در كلاسهاى وززشى، خيلى اهميت داره" ( استاد ا، مرد باه ساله). مشاركت كننده ديخرى بيان داشت: "والدينم، هميشه تمام هزينههايى كه مورد نيازمه براى ورزش بهم مى دن" ( مصاحبه گروهى دانشجوى "ا، زن، آ ساله). ويثزگىهاى ذكر شده فوق را مىتوان در زير مقوله "حمايت ابزارى و مستقيم والدين "دسته بندى نمود. بنابراين، همه ويثزى هاى ذكر شده فوق كه به نوعى مى توانند موجب شكل گيرى رفتار فعاليت بدنى دانشجويان شده و يا به نوعى از آن حمايت نمايد در مقوله اصلى " حمايت خانواده و دوستان " دسته بندى گرديد. مقوله اصلى حمايت مربيان و كارشناسان ورزشى دانشگاه به نظر مىرسد حمايت مربيان و استادان تربيت بدنى و علوم وززشى 
فعاليت ها به آنها، باعث ارتقاى سطح عملكرد و انكيزه مشاركت

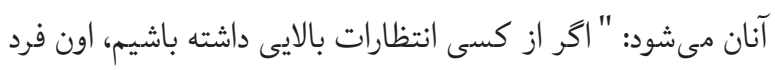

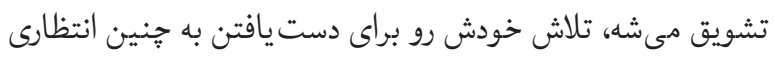
بالاتر مىبره" (استاد •†). مشاركت كننده ديكرى بيان داشت: "مربيانم

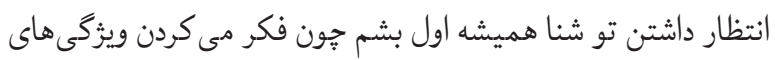

خاصى دارم كه براى شنا مهمه ( دانشجوى (l).

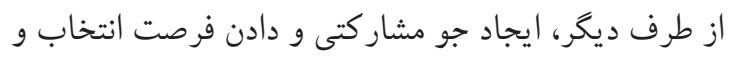

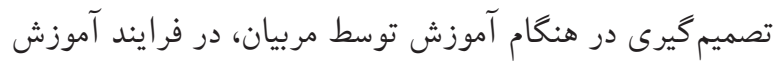

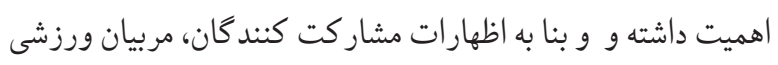
بايد بطور مداوم دانشجويان را به ارائه يِيشنهاد تشويق كرده و از آنها بخو اهد كه نظر ات خود رادر مورد مسائل مورد نظر بيان كنند.

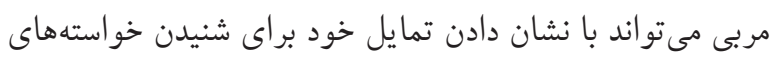
دانشجويان، به آنها نشان دهد كه برايشان ارزش قائل مىباش داند.

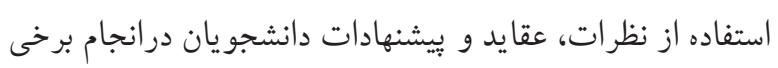

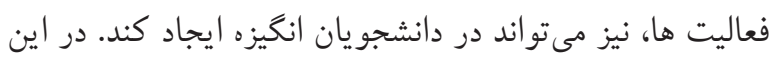

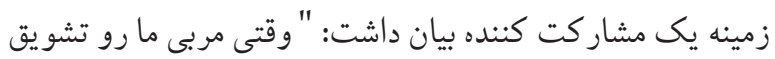

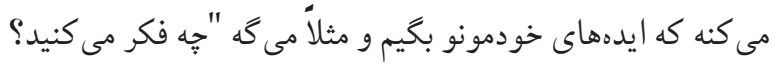

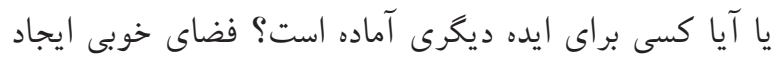

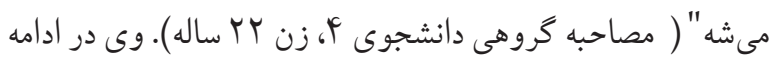
كفت: "... شما احساس مى كنيد كه نظرات شما در كروه شنيده مىشود". مشاركت كنند گان، به اهميت مشار كت دادن دانشجو يان

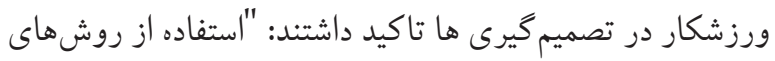

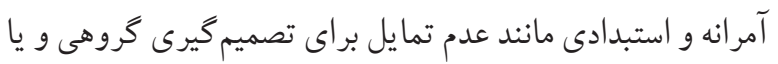

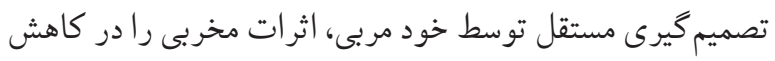

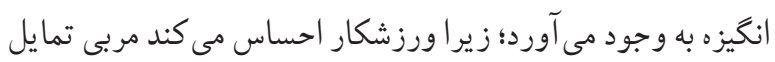
جندانى براى تصميم گيرىهاى گروهى ندارد و او فقط بايد وظيفه خاصى را كه بر عهده اش است انجام دهد ( استاد • (Y).

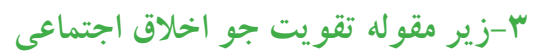
اخلاق به وسيله افراد به وجود مى آيد؛ اما حاصل فعاليت اخلاقى اين افراد، در تأثيرات متقابل اجتماعى، تغيير شكل مى يابد. اكثريت افراد، تحت تأثير اخلاق، امكان انجام كارهاى آكاهانه تر و فداكارانه
كندة كان بود: "مربيان موفق بايد با ورزشكاران خود همدل باشند، مثلاً وقتى كه دانشجويان مضطرب و نار احتند، يا اينكه مثلاً از شكستهاشون و يا از يك ناكامى تو ورزش عصبانى هستند و يا ينكه كلاً برعكسش، موفق شدن و شاد و خوشحالند، مربيان بايد

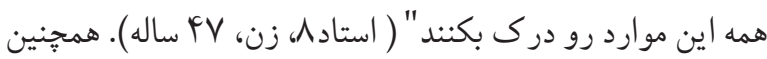

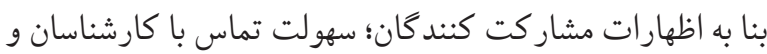

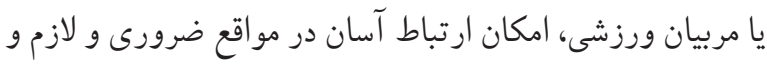
امكان كفتخو و صحبت جهت راهنمايى و حل مشكلات و به طور كلى در دسترس بودن كارشناسان ورزشى اهميت بسيارى دارد. در ور ورد

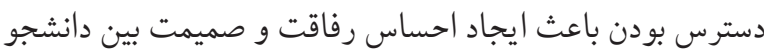
و مربى شده و كارشناسان و مربيان ورزش دانشكاه مىبايست بـان

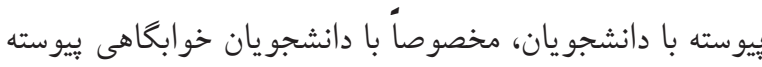

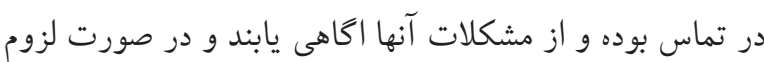
به ورزشكاران در حل مشكلات كمك نمايند:"مربيان بايد بطور مر تب با دانشجويان در تماس باشن و اطلاعات شخصى بازيكنان

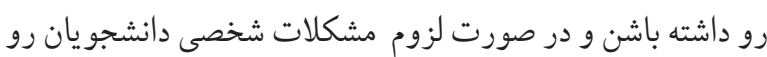

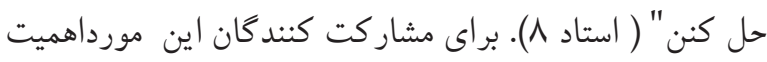

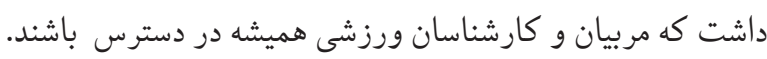
ب-زير مقوله حمايت از شايستخى و استقلال عواملى مانند بازخورد و پاداش، احساس شايستخى را ارتقا مى دهند

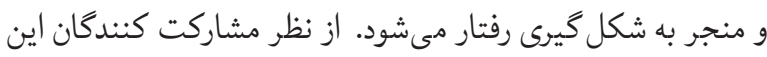

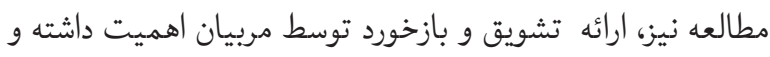

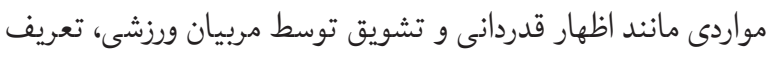

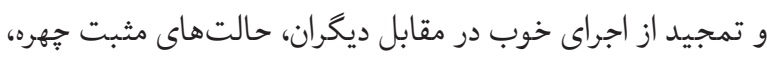
لبخند و تاييد جشمى، در جهت بهبود عملكرد، به طور مرتب و در مصاحبههاى مختلف عنوان گرديد. مشاركت كنندهاى در اين زمينه

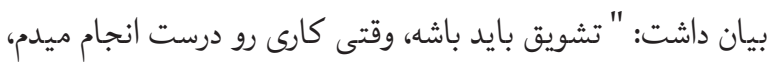

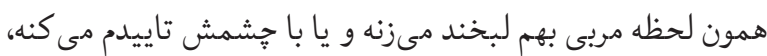

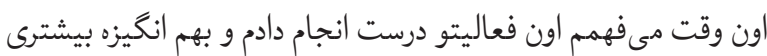

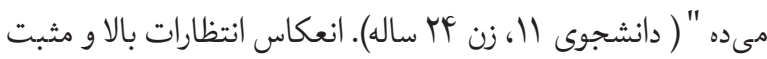
به دانشجويان، تأييد توانايى و دادن اطمينان خاطر توانايى انجام 
بهمون اجازه نمى دن با لباس راحت ورزش كنيم. دوجرخه سوارى

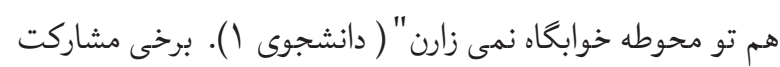

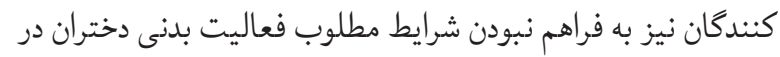

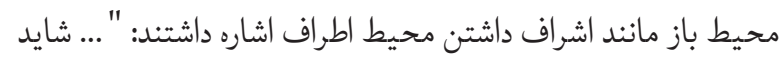
خيلى دخترا فوتبال جمن را دوست داشته باشن و يا تنيس خاكى رون

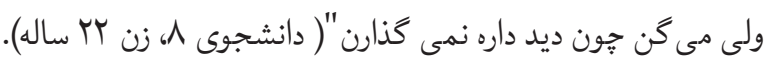

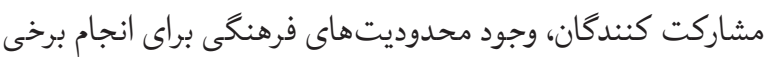
فعاليتهاى بدنى دلخواه بانوان در دانشگاه، مانند انجام دوجرخه سوارى، اسكيت، تنيس خاكى، فوتبال در جمن و...را بيان نموده و بر ضرورت افزايش رشتههاى ورزشى مورد علاقه دانشجويان دختر تأكيد داشتند. محدوديتهاى فرهنكى از جمله موانع مهمى بودند

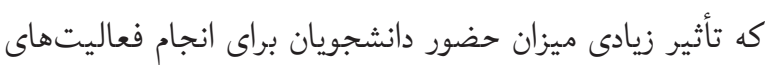

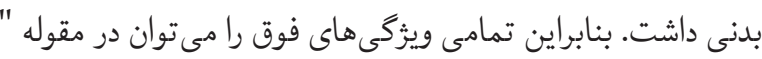
قوائد جنسيتى فرهنكى "دسته بندى كرد.

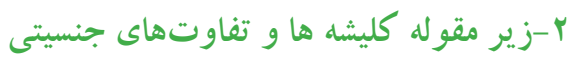
تفاوتهاى جنسيتى در عملكرد والدين و نيز وجود باورهاى قالبى

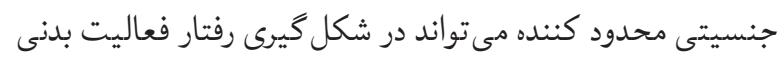
دانشجويان نقش مهمى داشته باشد. مشاركت كنندگان در مطالعه

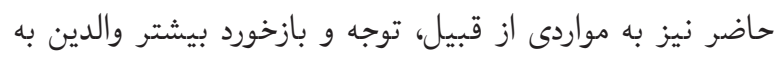

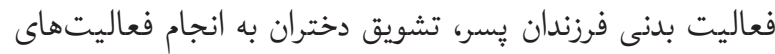

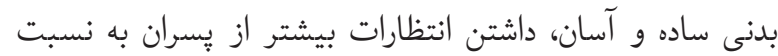
دختران، اهميت بيشتر به فعاليت بدنى فرزندان پِسر، داشتن باور

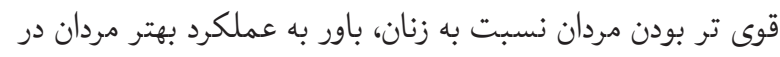

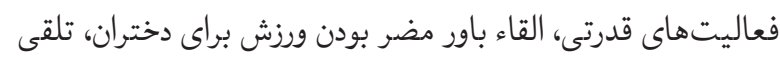
ورزش به عنوان امرى مردانه، باور به مردانه شدن اندام دختران در بـ بردي نتيجه بدنسازى، نكرش منفى والدين براى فعاليت بدنى دختران و....

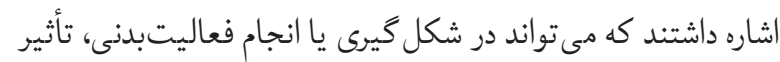

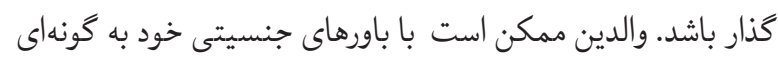

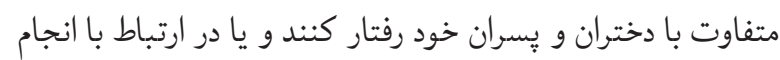

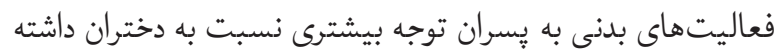

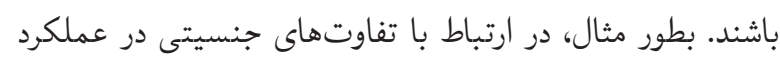

تر را يبيدا مى كنند. تاكيد بر ترويج و توسعه اخلاق و اخلاق مدارى در كنار يرورش جسم نيز، بخشى از زمينه كارى و وظايف مربيان

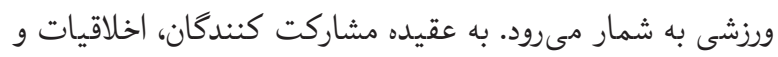
تقويت ارزشهاى معنوى در دانشجويان در ورزش يايد مورد توجه قرار كيرد و فراهم سازى تجربه اصول ارزشى و اخلاقى براى دانشجويان در محيطهاى ورزشى از اهميت خاصى برخوردار است. تشويق و و

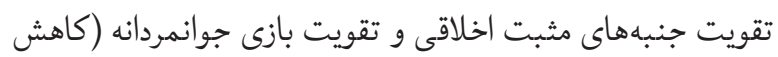
خشونت در محيط ورزشى و كاهش رفتارهاى غير اخلاقى) لازم است. يكى از مشاركت كنندكان دراين زمينه، كفت: "بايد ارزشهاى

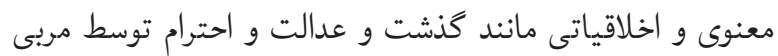

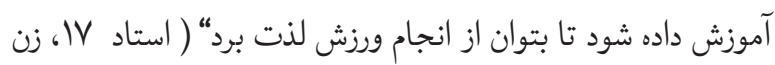

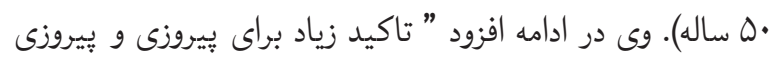
به هر قيمتى ممكن است باعث بروز رفتارهاى غير اخلاقى بشه".

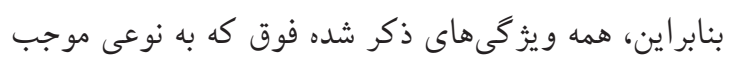

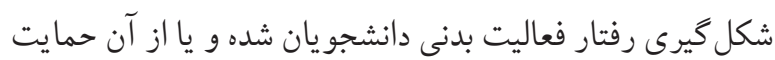

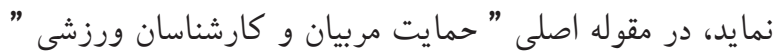
دسته بندى گرديد.

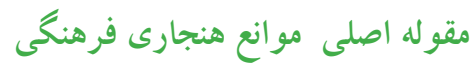
نتايج در اين بعد در قالب دو زير مقوله قوائد جنسيتى فرهنكى و و مولى كليشه ها و تفاوتهاى جنسيتى دسته بندى شد. 1-زير مقوله قوائد جنسيتى فرهنگ وجود ضوابط و مقررات يوشش و همجنين وجود محدوديتهاى

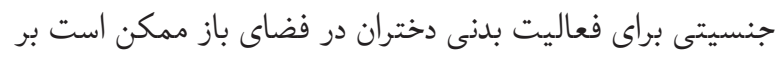

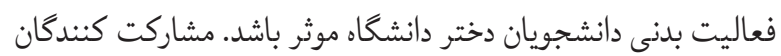
در يُوهش حاضر نيز به مواردى مانند؛ ضوابط سبك يوشش، مشرف

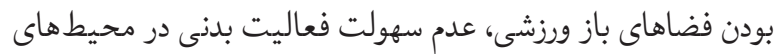

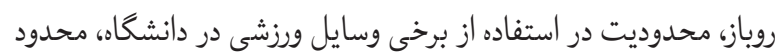

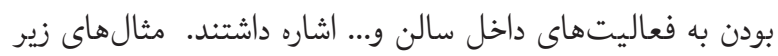

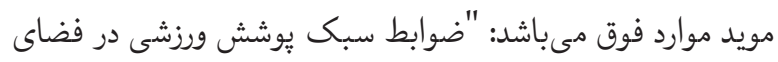

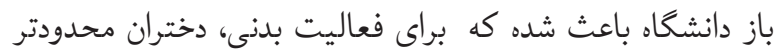

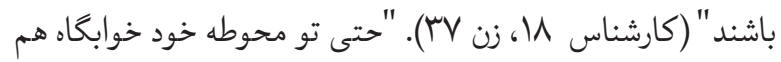


بحث

يافتهاى مطالعه حاضر نشان داد كه مىتوان عوامل محيط اجتماعى بحى

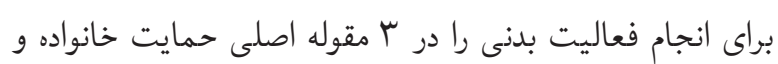

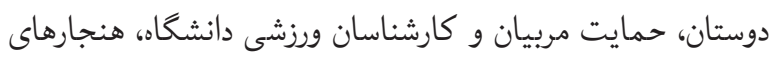

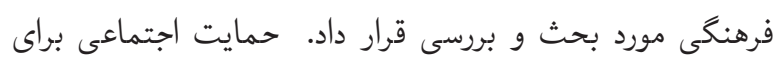

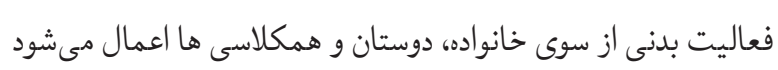
و از آنجا كه فعاليت بدنى از عوامل اجتماعى شدن به شمار مى ردود،

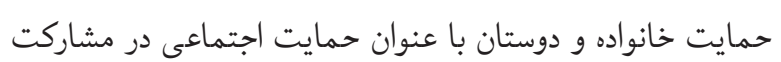
در فعاليتهاى بدنى تاثير مستقيم دارد (سابت). با توجه به نتايج كيفى، مىتوان نتيجه كرفت، نقش خانواده و بدون شك محيط

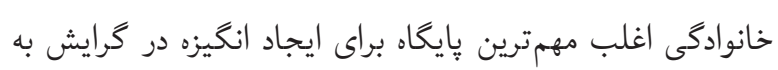

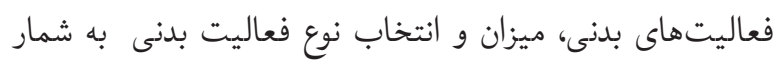

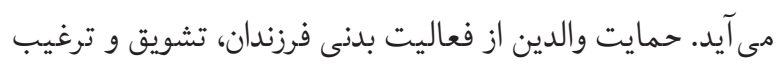

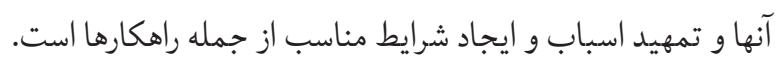

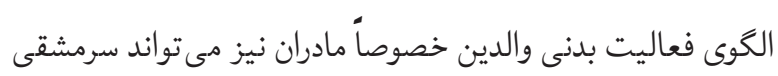
براى فرزندان باشد. والدينى كه براى خود برنامه فعاليت بدنى دارند،

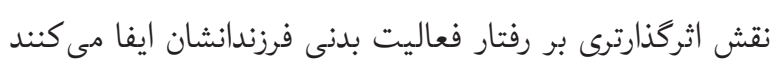

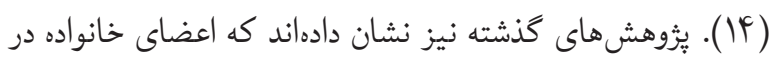
حالتهاى متفاوت و روشهاى مختلف مى توانند بر مشاركت افراد

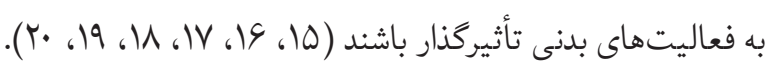

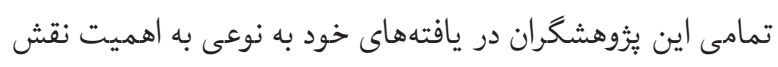

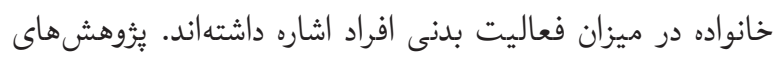
متفاوت ديكرى نيز نشان مىدهند كه به احتمال فراوان، فرزندان والدينى كه تحرك و فعاليت بدنى كمترى دارند، نسبت به والدينى

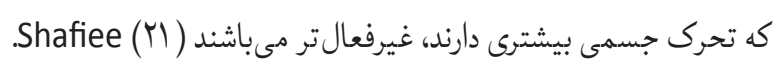

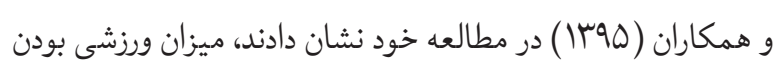

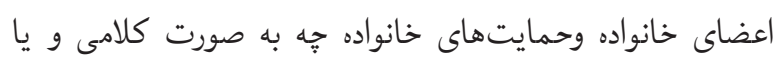
مشاركت خود والدين در فعاليتهاى جسمانى، اثر مهمى در فعاليت ونايت

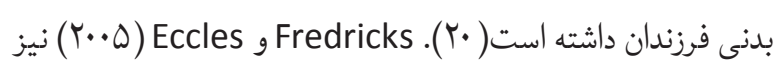
بيان داشتند، والدين با سه شيوه مىتوانند بر فرزندشان تأثيركذار

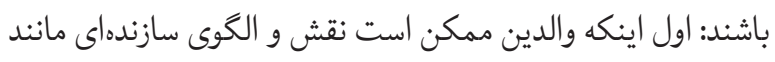

والدين يكى از مشاركت كنندگان بيان داشت: " ...در مورد انجام فعاليت بدنى و ورزش يسران ممكن است توجه بيشترى از والدين

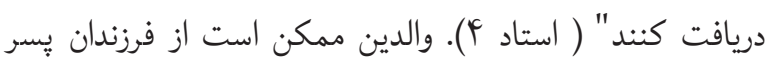

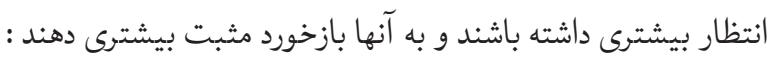

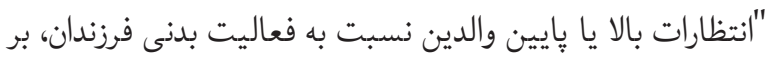

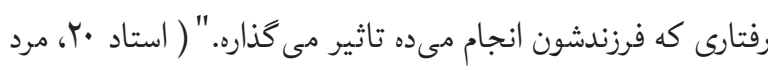

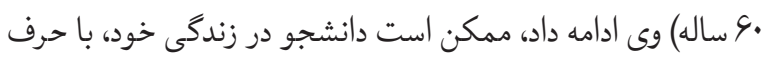

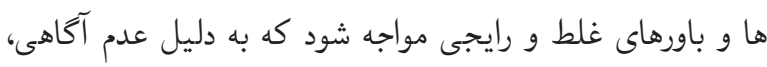

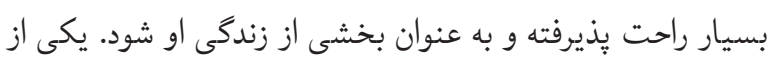

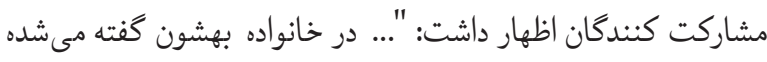

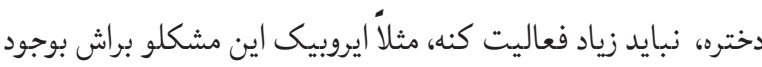
مى ياره و يا اسب سوارى فلان مىشه و بعد اين باور اشتباه در اون

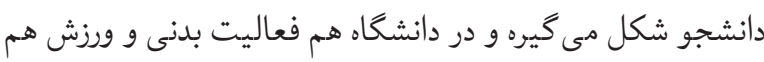

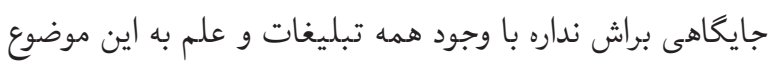

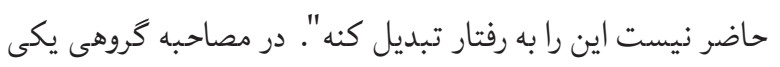
از مشاركت كنندگان گفت: " مادرم بعضى اوقات بهم مى گكه، تو دخترى نبايد بدنسازى كار كنى اندامت مردونه مىشه " (مصاحبه

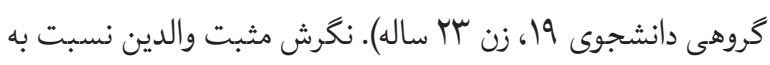
عملكرد يسران در برخى فعاليتهاى بدنى، موجب باور بهتر يسران

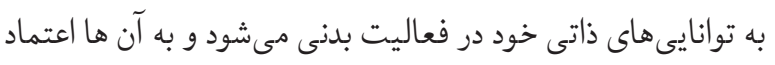
به نفس مىدهد در حالى كه نكرش غلط، منفى و يا تحقيرآميز آنها

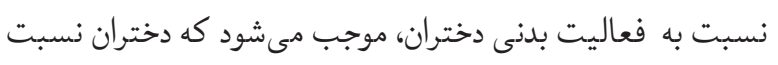

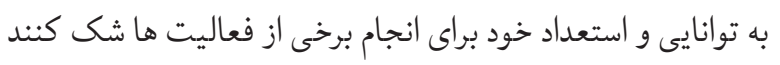

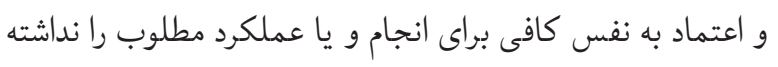
باشند. بنابراين تمامى ويزگى هاى مربوط به زير مقوله هاى فوق را

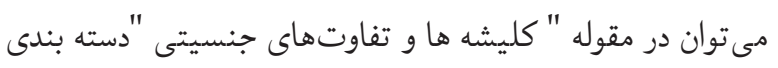

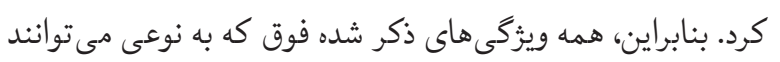
در شكل گيرى رفتار فعاليت بدنى دانشجويان مرتبط باشند در مقوله اصلى " موانع هنجارى فرهنگى" دسته بندى گرديد. 
ادراك دانشجويان پِر از حمايت محيطى همسالان و حمايت اجتماعى دوستان در سطحى بالاتر از دانشجويان دختر قرار دارد

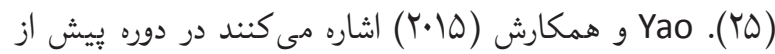
نوجوانى، والدين نقش مهمى در تثبيت اجتماعى يذيرى فعاليتهاى

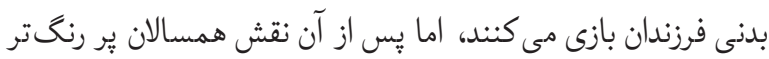

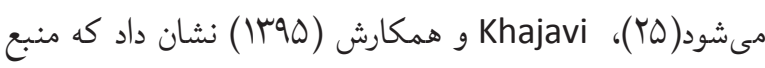
حمايت اجتماعى دوستان، ييش بينى كننده فعاليت بدنى دانشجويان

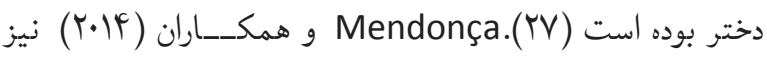
دريافتنــد، نوجوانانى كـه هم حمايــت اجتمـاعى والدين و هم حمايـت دوسـتان خود را دريافت كردند، سطوح بالاترى از فعاليت بدنى را نشان مى دهند (Y)). بنابراين خانواده، دوستان و همسالان مى توانند نقش مهمى در فعاليت بدنى دانشجويان داشته باشند كه

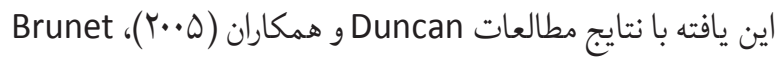

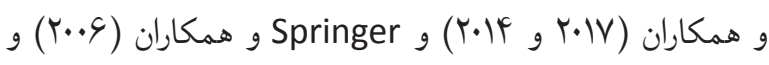
Vahida 19). از طرف ديكر، كاهش رفتار حمايت اجتماعى مربيان و كارشناسان ورزشى مىتواند به بى انكيزگى دانشجويان منجر شود، بنا بر تجزيه

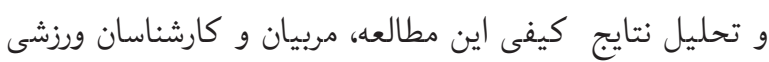
دانشكاه نيز نقش مهمى براى فعاليت بدنى دانشجويان ايفا مى كنند و مشاركت كنندكان بر لزوم ارتباط صميمانه و برخورد توأم با احترام

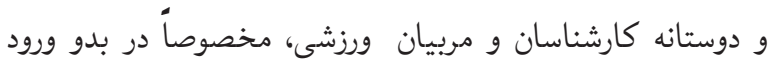

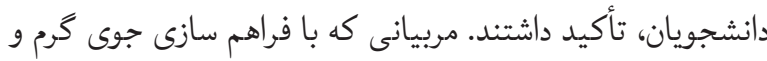
صميمانه، به راحتى با دانشجويان خود ارتباط يِيدا مي كنند، بر انكيزه

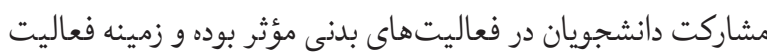

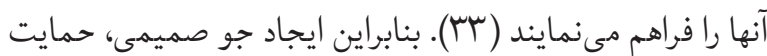
كننده و تشويقى توسط مربيان ورزشى مىتواند بر فعاليت بدنى مراني

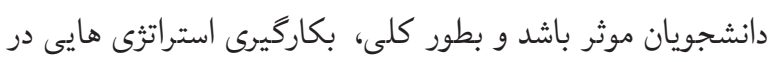
جهت تقويت تعاملات لذت بخش دانشجويان در برنامههاى فعاليت بدنى دانشخاه، اينكه تا جه حد افراد در گروه و در تعاملات با ديكران

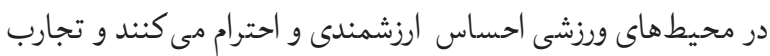
ييامدهاى رفتار بين فردى و تجريه عاطفى آن اهميت دارد. يك درسى
مربيكرى به فرزندان ايفا كنند، يا خودشان در فعاليتهاى ورزشى شركت كنند و يا تفاسير و بياناتى از تجربه خود راجع به شركت

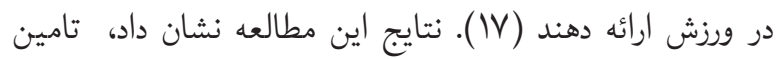

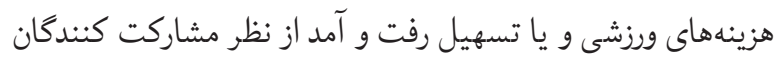

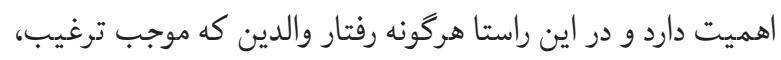
انجام و ادامه فعاليت بدنى فرزندان باشد، فعاليت بدنى آنها را نيز دوريز افزايش مى دهد و بالعكس، حمايت اجتماعى پايين منجر به كاهش كرايش به فعاليتهاى ورزشى و تفريحات سالم مىشود. Kurc و و Leatherdale קِران با حمايت اجتماعى پايين تر، شانس كمترى نسبت به همسالان خود براى شركت در فعاليتهاى بدنى دارند(Y) Naderian

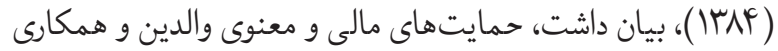

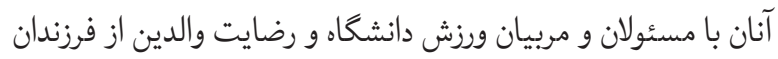

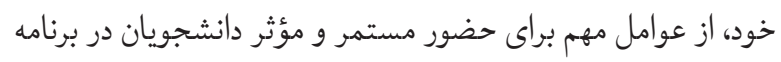

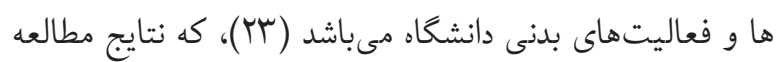

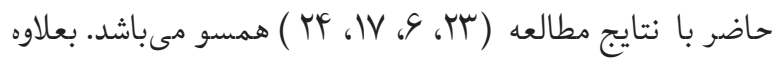
با توجه به نتايج كيفى اين تحقيق، به نظر مىرسد دوستان و همسالان

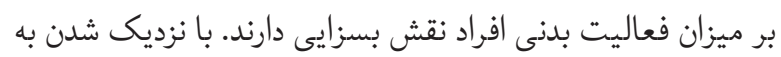

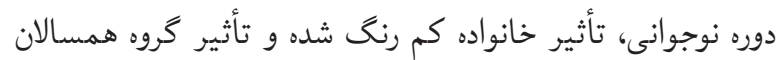

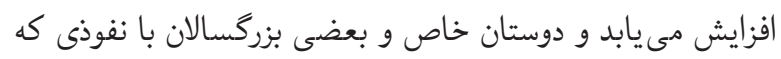

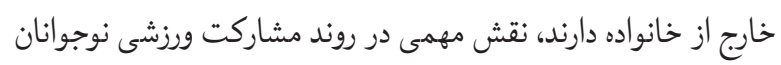

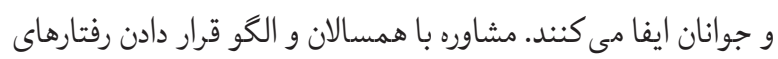
ييشكسوتان مورد احترام، اغلب از الحوهاى تأثيرگذار براى ايجاد تغييرات رفتارى در اين سنين به شمار مى رود. بنابراين، مى توان

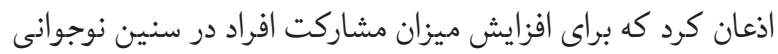
و جوانى در فعاليتهاى ورزشى مىتوان از نقش دوستان به منزله

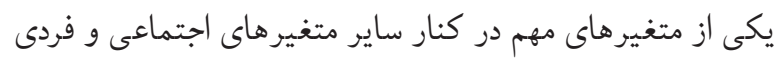

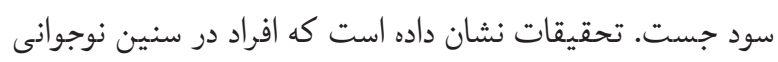
حدود • F درصد از وقتشان را با دوستان خود مى گذرانند. در واقع صرف وقت با دوستان و همسالان، تعلق خاطرى به گروه در ميان آنان به وجود مى آورد. GhasemNejad (1٪9 (1) بيان داشت؛ 
حاضر، دانشجويان دختر به نسبت بِران براى فعاليت بدنى در

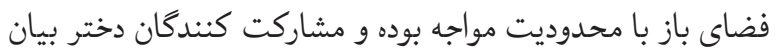

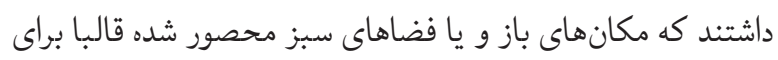
فعاليت بدنى آنان مناسب نبوده و نمى توانند با خيال راحت حجاب مهاب

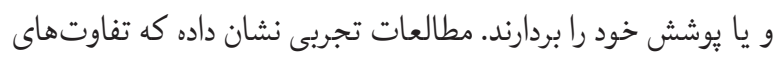
جنسيتى در زمينه فعاليتهاى بدنى و ورزشى وجود دارد و زنان در

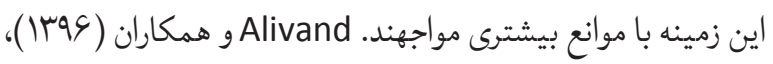
نيز بيان داشتند، بين هنجارهاى جنسيتى با مشاركت ورزشى زنان ينان

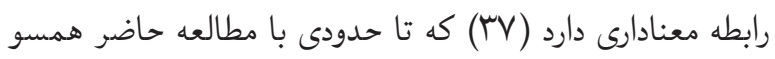

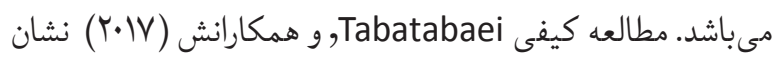
داد، اكثر زنان ترجيح مى دهند فعاليت بدنى را در يك محيط امن مدي

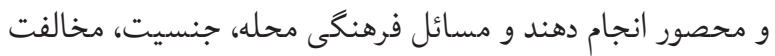

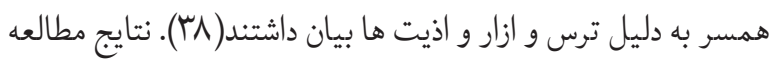
Pirasteh خوابگاه نسبت به خارج خوابگاه براى دختران داراى اهميت بيشترى مىباشد و اين به علت دلائل فرهنكى و محيطى است كه دختران دانشجو در فضاى خوابكاه و منزل امكان بيشترى براى انجام فعاليت

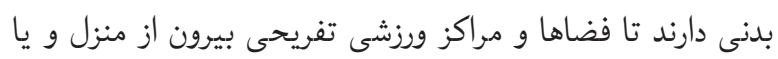

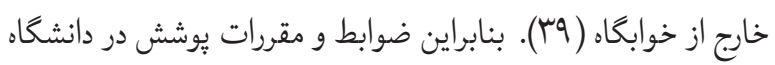
و همجنين محدوديت هاى فعاليت بدنى دختران در فضاى باز، ممكن

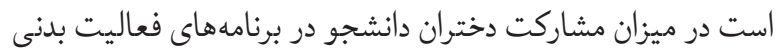

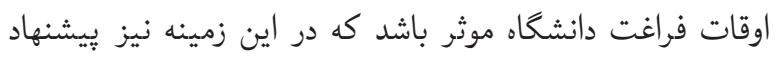

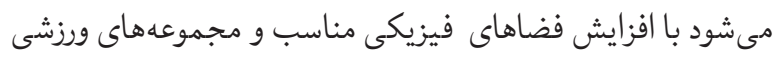

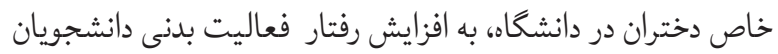
كمك نمود. مطالعه كيفى حاضر نشان داد، تفاوتهاى جنسيتى موجود در عملكرد والدين و بهمراه باورهاى قالبى جنسيتى موجود مى تواند نقش موثرى در رفتار فعاليت بدنى دانشجويان داشته باشد.

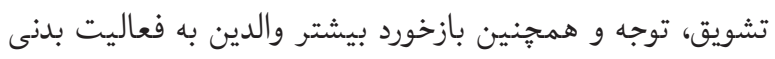
فرزندان پِسر به نسبت دختران، داشتن انتظارات بيشتر از يسران و

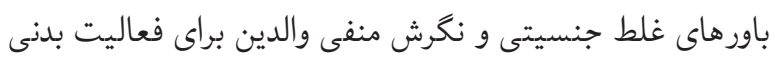

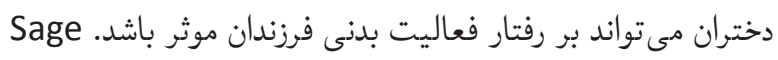

ستراتزى، آموزش دادن مربيان و كارشناسان ورزشى دانشگاه براى ارزش كذارى به اين موضوع مى باشد. طبق تجربيات مشاركت كنندكان،

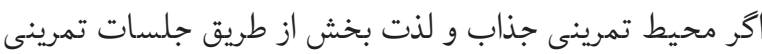
متنوع و مهيج، ايجاد شود، مىتواند بر ميزان فعاليت بدنى افراد بهري

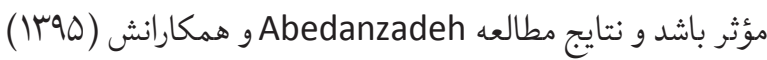
نشان مىدهد، كه فراهم سازى شرايط تمرينى همراه با احساسات

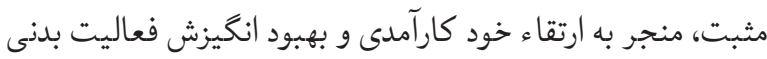

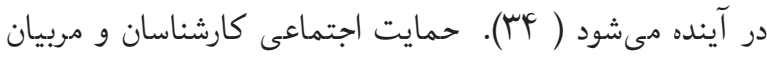

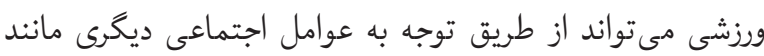
حمايت از شايستكى و استقلال دانشجويان انجام يذيرد. بطوريكه

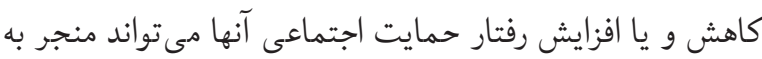

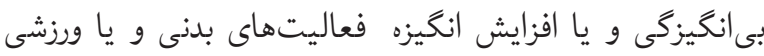

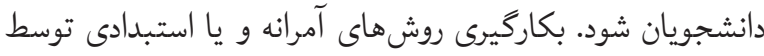
مربيان و يا كارشناسان ورزش دانشخاه موجب كاهش انخيزه دانشجويان شده، بنابراين استفاده از نظرات، عقايد و يِيشنهادات دانشجويان درانجام برخى فعاليت ها، مى تواند موجب افزايش انگيزه فعاليت بدنى دانشجويان شود. از سوى ديكررعايت اصول اخلاقى و اخلاقيات در محيطهاى ورزشى نيز توسط مشاركت كنندگان اشاره شد. اخلاق غالباً به يك مجموعه اصول اخلاقى يا ارزش هايى اطلاق مىشود نها

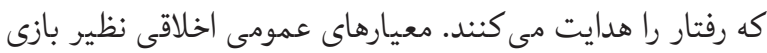

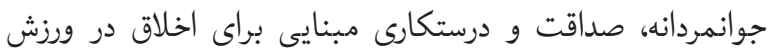

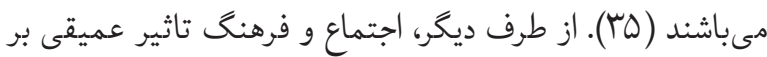
رفتارهاى حركتى و فعاليت بدنى افراد دارند. در برخى جوامع يارهاى

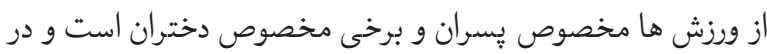

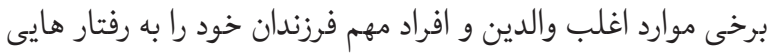
تشويق مى كنند كه مناسب يك جنس است و جامعه نيز ممكن

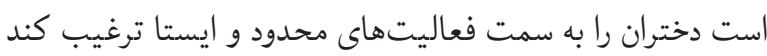

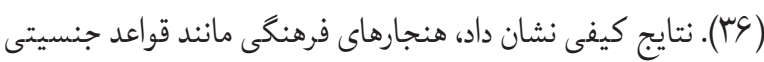
فرهنكى و تفاوتهاى جنسيتى اهميت داشته و وجود برخى ضوابط مقررات و يا محدوديتهاى فرهنكى مخصوصا براى دانشجويان

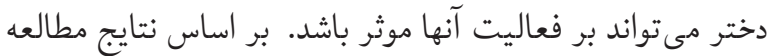




$$
\begin{aligned}
& \text { جنسيتى ضرورى به نظر مىرسد. } \\
& \text { نتيجه كيرى }
\end{aligned}
$$

به طور كلى، به نظر مىرسد عوامل محيطى اجتماعى در ارتباط با

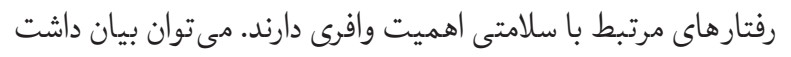

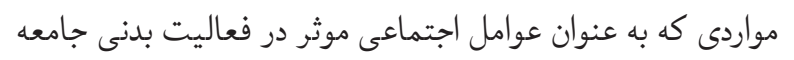
جوان دانشخاهى معرفى شدند، بصورت زنجيروار به هم مرتبط بوده و جهت برنامه ريزى فعاليت بدذى دانشجويان بررسى و شناسايى

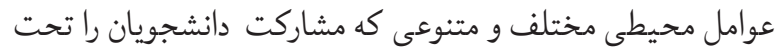

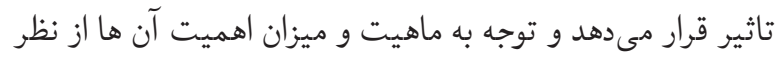
اساتيد، كاركنان و دانشجويان ضرورى مى باشد. بنابراين براى كليه

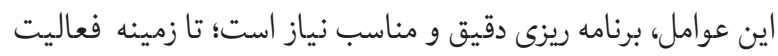
بدنى و مشاركت فعال اين قشر از جامعه جوان فراهم كردد. سياسگزارى

اين مطالعه حاصل يافته هاى باياننامه دكترى مديريت ورزشى سركار

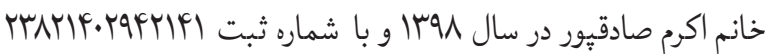
معاونت يُزوهشى دانشكده تربيت بدنى و علوم ورزشى دانشكاه آزاد

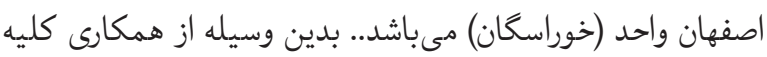

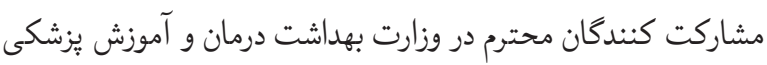

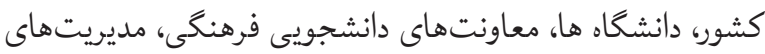

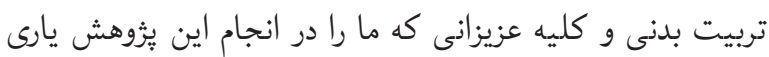

$$
\text { تمعودند، تشكر و قدردانى مى گردد. }
$$

در اين مقاله هيج گونه تعارض منافعى وجود ندارد.

\section{References}

1. Mansourizadeh M, Anoosheh M, KazemNejad A. The Effect of Physical Activity Program Based on Pender Health Promotion Model on Type 2 Diabetic MiddleAged Women's Mental Health. Iranian Journal of Health Education and Health Promotion. 2018;6(2):159-67. [DOI:10.30699/acadpub.ijhehp.6.2.159]

2. Peyman N, Rezai-Rad M, Tehrani H, Gholian-Aval M, Vahedian-Shahroodi M, Miri HH. Digital Media-based Health Intervention on the promotion of Women's physical activity: a quasi-experimental study. BMC public health. 2018;18(1):134. [DOI:10.1186/s12889-018-5025-
(191) نيز در مطالعه خود با عنوان "نقش والدين و جامعه يذيرى ) ورزشى ورزشكاران همدانشكدهاى دختر و پِّر "بيان داشت، والدين

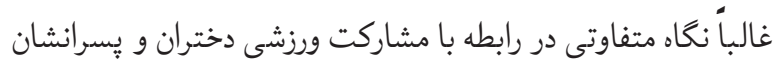
دارند و پِدران حمايت بيشترى از يسرانشان در مقايسه با دخترانشان

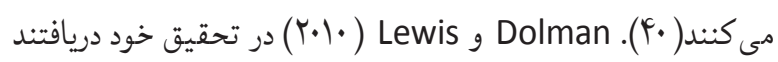
دخترانى كه از سطوح پايينترى از حمايت كلامى و عاطفى از سوى والدين براى ورزشكار كردن برخوردار بودند، مشاركت كم ترى در

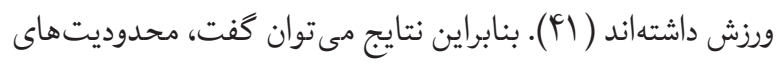
فرهنكى و اجتماعى، باور ها و اعتقادات مذهبى و سنتى حاكم در

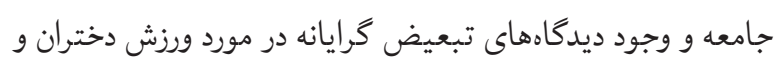

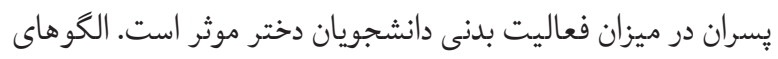

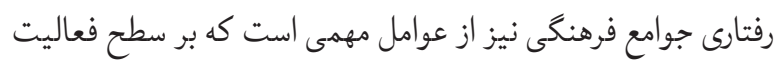

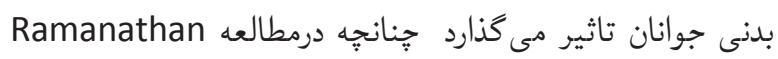

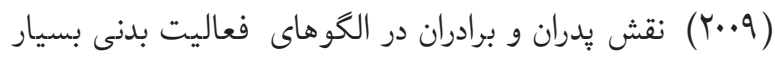

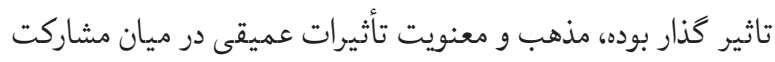
كنندگان در فعاليتهاى بدنى در فرهنگ هندى داشته و نتايج نشان داده كه ميراث فرهنكى بر هنجارها، نكرش ها و الخوها تاثير مى كذارد

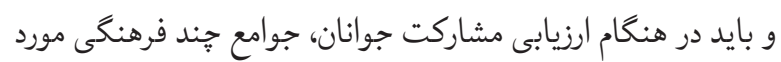

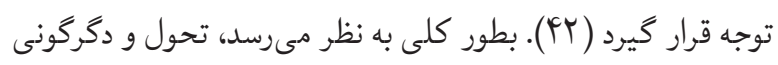

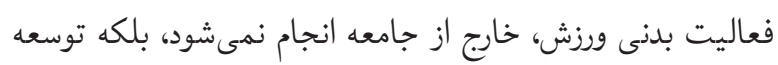

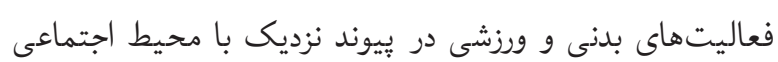

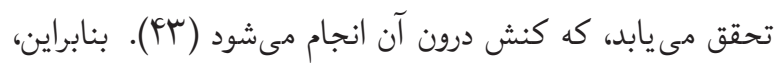

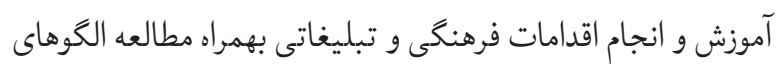
رفتارى فرهنكى جهت تاثير بر نحرش و و شكل ونيرى باورهاى

\section{5] [PMID] [PMCID]}

3. Goje M, Salmiah MS, Ahmad Azuhairi A, Jusoff K. Physical inactivity and its associated factors among university students. IOSR Journal of Dental and Medical Sciences. 2014;13(10):119-30. [DOI:10.9790/0853-13101119130]

4. Young SJ, Sturts JR, Ross CM. Physical activity among community college students. Physical Educator. 2015;72(4):640. [DOI:10.18666/TPE-2015-V72-14-7140]

5. Odat J. The Reasons for the Reluctance of Princess Alia University College Students' from Practicing Sports Activities. International Education Studies. 2015; 8(4):40- 


\section{1. [DOI:10.5539/ies.v8n4p40]}

6. Hosseini S.E, Pourkiani M, jami Alahmadi A, Afroozeh A. Determine Affecting Factors on Increasing Students 'Physical Activity Participation. Research on Educational Sport. 2016; 5(12): 97-114. [DOI:10.22089/res.2017.941]

7. Parto S, Izadi Ms, Karimimoshaver M, Zaboli R. Urban Open Spaces Supporting Physical Activity and Promoting Citizen's Health: A Systematic Review. Iranian Journal of Health Education and Health Promotion. 2019;7(2):12642. [DOI:10.30699/ijhehp.7.2.126]

8. fathi F, Rezaei sofi M. The Relationship between Health Literacy and Physical Activity Level of Elderly Women in the City of Urmia. Journal of Health Literacy. 2017;2(1):1221. [DOI:10.22038/jhl.2017.10947]

9. Elo $S$, Kyngäs $H$. The qualitative content analysis process. Journal of advanced nursing. 2008;62(1):107-15. [DOI:10.1111/j.1365-2648.2007.04569.x] [PMID]

10. Peyman N, Ezzati Rastegar K, Tehrani H, Zarei F. Explanation of unwanted pregnancy from the perspective of family planning service providers: An exploratory study. The Iranian Journal of Obstetrics, Gynecology and Infertility. 2016;19(12):18-26..

11. Polit DF, Beck CT. Essentials of nursing research: Appraising evidence for nursing practice. Lippincott Williams \& Wilkins; 2009.

12. Jowett $S$, Chaundy V. An investigation into the impact of coach leadership and coach-athlete relationship on group cohesion. Group Dynamics: Theory, Research, and Practice. 2004;8(4):302. [DOI:10.1037/1089-2699.8.4.302]

13. Kahn EB, Ramsey LT, Brownson RC, Heath GW, Howze $\mathrm{EH}$, Powell KE, et al. The effectiveness of interventions to increase physical activity: a systematic review. American journal of preventive medicine. 2002;22(4):73-107. [DOI:10.1016/S0749-3797(02)00434-8]

14. Cantell M, Wilson A, Dewey D. The motivational state and perceived benefits and barriers to physical activity participation in parents of preschool age children. Science \& Sports. 2014;29:S42 [DOI:10.1016/j.scispo.2014.08.083]

15. Kenyon GS, McPherson BD. An approach to the study of sport socialization. International Review of Sport Sociology. 1974;9(1):127-39. [DOI:10.1177/10126902740 0900109]

16. Weiss MR, Knoppers A. The influence of socializing agents on female collegiate volleyball players. Journal of Sport and Exercise Psychology. 1982;4(3):267-79. [DOI:10.1123/ jsp.4.3.267]

17. Fredricks JA, Eccles JS. Family socialization, gender, and sport motivation and involvement. Journal of sport and Exercise Psychology. 2005;27(1):3-31. [DOI:10.1123/ jsep.27.1.3]

18. Sanz-Arazuri E, Ponce-de-León-Elizondo A, ValdemorosSan-Emeterio MÁ. Parental predictors of physical inactivity in Spanish adolescents. Journal of sports science \& medicine. 2012;11(1):95.

19. Parsa Mehr, Arizi f, Vahida F. Effect of Social Support on Women's Participation in Sport Activities (Case Study: Women of Mazandaran Province). Journal of Movement Science and Sports. 2006;1(7):53-62.

20. Shafiee Sh, Boroumand M, Hojabr K, Salkhi S. The Relationship Between Some Socialization Factors with Growing Youth Participation.Interdisciplinary Studies in the Humanities. 2016;8(3):113-126

21. Singh GK, Kogan MD, Siahpush M, Van Dyck PC. Independent and joint effects of socioeconomic, behavioral, and neighborhood characteristics on physical inactivity and activity levels among US children and adolescents. Journal of community health. 2008;33(4):206-16. [DOI:10.1007/ s10900-008-9094-8] [PMID]

22. Kurc AR, Leatherdale ST. The effect of social support and school-and community-based sports on youth physical activity. Canadian journal of public health. 2009;100(1):604. [DOI:10.1007/BF03405495] [PMCID]

23. Naderian Jahromi. Basics of Sociology in Sport. isfahan: Publishing of beautiful art 2005

24. Liu Y, Zhang Y, Chen S, Zhang J, Guo Z, Chen P. Associations between parental support for physical activity and moderate-to-vigorous physical activity among Chinese school children: a cross-sectional study. Journal of sport and health science. 2017;6(4):410-5. [DOI:10.1016/j. jshs.2017.09.008] [PMID] [PMCID]

25. Ghasem Nejad, M. Gender differences in student perception of environmental and social support for participation in physical activity. Mental behavior and exercise psychology. 2010;7(2):79-90

26. Yao CA, Rhodes RE. Parental correlates in child and adolescent physical activity: a meta-analysis. International Journal of Behavioral Nutrition and Physical Activity. 2015;12(1):10. [DOI:10.1186/s12966-015-0163-y] [PMID] [PMCID]

27. Khajavi D, Shahbazi N. Predicting Physical Activity Level of Female College Students based upon Sources of Perceived Social Support. JSR. 2016;17(2):108-16.

28. Mendonça G, Cheng LA, Mélo EN, de Farias Júnior JC. Physical activity and social support in adolescents: a systematic review. Health education research. 2014;29(5):822-39. [DOI:10.1093/her/cyu017] [PMID]

29. Duncan SC, Duncan TE, Strycker LA. Sources and types of social support in youth physical activity. Health psychology. 2005;24(1):3. [DOI:10.1037/0278-6133.24.1.3] [PMID]

30. Brunet J, Gaudet J, Wing EK, Bélanger M. Parents' participation in physical activity predicts maintenance of some, but not all, types of physical activity in offspring during early adolescence: A prospective longitudinal study. Journal of sport and health science. 2019;8(3):273- 


\section{9. [DOI:10.1016/j.jshs.2017.04.012] [PMID] [PMCID]}

31. Brunet J, Amireault S, Chaiton M, Sabiston CM. Identification and prediction of physical activity trajectories in women treated for breast cancer. Annals of Epidemiology. 2014;24(11):837-42. [DOI:10.1016/j. annepidem.2014.07.004] [PMID]

32. Springer AE, Kelder SH, Hoelscher DM. Social support, physical activity and sedentary behavior among 6thgrade girls: a cross-sectional study. International Journal of Behavioral Nutrition and Physical Activity. 2006;3(1):8. [DOI:10.1186/1479-5868-3-8] [PMID] [PMCID]

33. Maziari M, Kashef SM, Seyed Ameri MH. Relationship between Social Support Behavior of Physical Education Teachers and motivation of Student in Physical Education Activities. Research in Sport Management \& Motor Behavior. 2016;6(11):41-50.

34. Abedan zadeh R, Heylavi neysi M, Ashraf poor Navayi S. The Effect of Normative Feedback on Performance and Learning of Throwing Task: The Role of Perceived Competence. Neuropsychology. 2016;2(5):83-96.

35. Mehrtak M, Hemmati A, Bakhshzadeh A. Health Literacy and its Relationship with the medical, dietary Adherence and exercise in Patients with Type II Diabetes mellitus. Journal of Health Literacy. 2018;3(2):137-44. [DOI:10.22038/jhl.2018.32829.1003]

36. Mahmoudi K, Taghipoor A, Tehrani H, Niat H, VahedianShahroodi M. Stages of Behavior Change for Physical Activity in Airport Staff: a quasi-experimental study. Investigacion y educacion en enfermeria. 2020;38(1). e02

37. Alivand AN, Maleki A, Parsa Mehr M, Ghasemi H.
Sociological Explanation of Women's Sports Participation with Emphasis on Gender Norms (Case Study: Women in Ilam Province). Ilam Culture Quarterly.2017;18(56):31-8

38. Tabatabaei SV, Ardabili HE, Haghdoost AA, Nakhaee N, Shams M. Promoting physical activity in Iranian women: A qualitative study using social marketing. Electronic physician. 2017;9(9):5279. [DOI:10.19082/5279] [PMID] [PMCID]

39. Pirasteh A, Johari Z, Zafarghandi N, Kholdi N. Stages of Dairy Products Consumption Change by Medical Students: The Trans Theoretical Model. Alborz University Medical Journal. 2012;1(3):159-65. [DOI:10.18869/acadpub. aums.1.3.159]

40. Sage GH. Parental influence and socialization into sport for male and female intercollegiate athletes. Journal of sport and social issues. 1980;4(2):1-13. [DOI:10.1177/0193723 58000400201]

41. Dollman J, Lewis NR. The impact of socioeconomic position on sport participation among South Australian youth. Journal of science and medicine in sport. 2010;13(3):31822. [DOI:10.1016/j.jsams.2009.04.007] [PMID]

42. Ramanathan S, Crocker PR. The influence of family and culture on physical activity among female adolescents from the Indian diaspora. Qualitative Health Research. 2009;19(4):492-503. [DOI:10.1177/1049732309332651] [PMID]

43. Hashemi SZ, Moradi R. Investigating the role of family in sport sociability. Journal of Sociology of Iran. 2010;11(4):143-168. 